\title{
Ion Channels as Promising Therapeutic Targets for Melanoma
}

\author{
Aurélie Chantôme ${ }^{1}$, Marie Potier-Cartereau ${ }^{1}$, Sébastien Roger ${ }^{1}$, \\ Christophe Vandier 1 , Olivier Soriani ${ }^{2}$ and Virginie Joulin ${ }^{3}$ \\ ${ }^{1}$ Inserm, U921, Tours, 37032 France; Université François Rabelais, Tours, 37032 \\ ${ }^{2}$ CNRS UMR 6543, Institut de Biologie du Développement et Cancer, 06108 Nice, \\ ${ }^{3}$ Inserm U1009, Institut Gustave Roussy, Villejuif, 94805
}

France

\section{Introduction}

Even cancer is far from being considered a channelopathy; the field of ion and protein channel research in cancer is highly important as an emerging and proven point of intervention in disease. Like membrane receptors, ion channels are directly connected with and sensitive to the extracellular environment. During the last decade, the number of ionchannel types expressed in various cancers, including melanoma, was rapidly increased. Moreover several ion channels are selectively expressed in aggressive cancers and seem to be implicated in metastasis development. The growing number of patents relative to cancer therapy targeting channel proteins testifies to the interest of such novel therapeutic approaches.

The physiological significance of ion channels and transporters, as illustrated by the award of four Nobel Prizes in Physiology or Medicine (1963; 1991) and Chemistry $(1997,2003)$, is now accepted and established. Unlike transporters and exchangers, channel proteins form a pore through membranes allowing the selective passage of one or more ions (e.g. $\mathrm{K}^{+}, \mathrm{Na}^{+}$, $\mathrm{Cl}^{-}$), molecules (water) or charged atoms, through the lipid bilayer that is impermeable to these compounds. The modalities of channel opening or activation are diverse and varied: this can be performed by an external molecular stimulus (e.g. ligand), by a mechanical stimulus (e.g. cell volume, membrane tension or stretch), by electric stimuli (e.g. changes in membrane potential), by an intracellular second messenger (e.g. calcium, cAMP). Thus the classification of the channels (IUPHAR classification) is based on the channel activation mode and on the selective permeability of molecular species specific to each channel. Channel proteins are involved in the control of numerous and various physiological functions. Basically, these channels are responsible for a universal property for cellular membranes: the existence of resting membrane potential. Ion channels, mainly studied in excitable cells like muscle and neurons, are responsible for the transmission of the electric signals triggering physiological and biological phenomena such as nerve conduction or the cellular phenomenon of excitation - contraction coupling. Ion transporter $\left(\mathrm{Na}^{+} / \mathrm{K}^{+}\right.$-ATPase or simply known as sodium pump) is the membrane pump that generates the $\mathrm{Na}^{+}$and $\mathrm{K}^{+}$ gradients across the plasma membrane, driving many physiological processes. Another 
class of channels, water channels or aquaporins (AQP), allow water molecules to pass through the membrane much faster than by simple diffusion through the lipid bilayer, while preventing the ions to enter or exit the cell. Finally, channels participate in ionic homeostasis and in controlling the shape of the cell by regulating the water flows.

If in a physiological context, the expression of a particular channel protein is specific in one or several tissues or organs, conferring an appropriate biological function, this is not that is observed in a tumour context. As a general rule, the cancer cell hijacks a channel's normal physiological function to drive certain essential biological functions for tumour development (such as proliferation and migration/invasion). Melanoma cells are considered to be electrically non-excitable, however they express several types of voltage-activated channels (Allen et al., 1997), which is unusual in a non-excitable cell. Because melanocytes originated from neural crest-derived precursors, they have retained significant neuronal ability. It is therefore not surprising that melanocytes (and a fortiori melanoma cells) can express (re-express), ion channels involved in excitatory or sensory functions.

Data on the level of channel expression in melanocytes versus melanoma cells are highly fragmented. Few cases of aberrant expression between melanocytes versus melanoma cells have been described. 1) The channel is expressed only in melanoma cells but not in melanocytes and it helps in a particular biological function (e.g. enhanced cell migration by hijacking the $\mathrm{Ca}^{2+}$ activated $\mathrm{K}^{+}$channel SK3/KCa2.3). 2) The channel is expressed by nonmalignant melanocytes and is not functional in this context but acquires a function during the melanocyte-to-melanoma transition (e.g. anti-apoptotic activity of the P2X7 receptor). 3) Inversely, the expression of the channel belonging to transient receptor potential (TRP) cation channel subfamily M, TRPM1/Melastatin-1/MLSN-1, is decreased in melanomas according to melanoma aggressiveness and is useful as a prognostic marker for melanoma metastasis (see for review (Prevarskaya et al., 2007)). However, data and information relative to non-malignant melanocyte channel expression or function are scarce and have to be continued. Table 1 summarizes the channels expressed by and active in melanoma cells and/or melanocyte, and their assigned function.

Among channels expressed by melanoma cells, some of them contribute to cell survival, like the store-operated channel (SOC) and the P2X7R receptor, or to cell proliferation, like the SKCa channel SK2/KCa2.2 and the $\mathrm{Ca}^{2+}$-permeable channel TRPM8. Note that the ultimate function of those $\mathrm{Ca}^{2+}$-permeable channels is to favour $\mathrm{Ca}^{2+}$ entry into a cell. In melanoma cells, several of channels, the voltage-dependent $\mathrm{Na}^{+}$channel Nav1.6, the SKCa channel $\mathrm{SK} 3 / \mathrm{KCa} 2.3$ and the water channel AQP1, are involved in cell adherence and migration that, in fine, it might confer a metastatic ability.

Lastly, the significant role of channel proteins in melanomagenesis is reinforced by the systematic overexpression of the sigma 1 receptor in many types of cancer including melanoma. Even if the sigma 1 receptor is still an enigma, its most well-known action in biological systems is the regulation and modulation of many ion channels, including those known to be involved in melanoma cell biology, suggesting the existence of tumour specific channel macro-complexes. On the other hand, proliferation, apoptosis resistance and migration/adhesion of cancer cells are impaired by the modulation of sigma 1 receptor activity through mechanisms involving ion channels. By its aberrant expression in melanoma, the use of the sigma 1 receptor as a target for an imaging tracer (using a PET imaging probe) and for the specific delivery of therapeutic agents (using synthetic sigma ligands) is currently the subject of intensive investigation. 


\begin{tabular}{|c|c|c|c|c|c|}
\hline \multirow{2}{*}{$\begin{array}{l}\text { Ion Channel } \\
\text { Name }\end{array}$} & \multirow{2}{*}{$\begin{array}{l}\text { Ion Channel } \\
\text { Type }\end{array}$} & \multirow{2}{*}{$\begin{array}{l}\text { Biological } \\
\text { function in } \\
\text { Melanoma }\end{array}$} & \multicolumn{2}{|r|}{ Expression } & \multirow[b]{2}{*}{ References } \\
\hline & & & $\overline{\text { Melanocyte }}$ & Melanoma & \\
\hline SOC & \multicolumn{2}{|c|}{$\begin{array}{l}\text { Store Operated Cell survival } \\
\text { Channel }\end{array}$} & n.d. & $\begin{array}{l}\text { Murine (B16) } \\
\text { melanoma cell line }\end{array}$ & $\begin{array}{l}\text { (Fedida-Metula et al., } \\
\text { 2008; Feldman et al., } \\
\text { 2010) }\end{array}$ \\
\hline P2X7R & $\begin{array}{l}\text { ATP-gated } \\
\text { cation- } \\
\text { permeable } \\
\text { ionotropic } \\
\text { receptor }\end{array}$ & $\begin{array}{l}\text { Cell death } \\
\text { Cell } \\
\text { invasiveness? }\end{array}$ & $\begin{array}{l}\text { yes (not } \\
\text { functional) }\end{array}$ & $\begin{array}{l}\text { Human melanoma } \\
\text { cell lines \& MDA-MB- } \\
435 \text { S cell line }\end{array}$ & $\begin{array}{l}\text { (Bringmann et al., 2001; } \\
\text {-Deli et al., 2007; Greig et } \\
\text { al., 2003; Ohshima et al., } \\
\text { 2010; Slater et al., 2003; } \\
\text { Timar et al., 2006; White } \\
\text { et al., 2005) }\end{array}$ \\
\hline \multicolumn{4}{|c|}{$\begin{array}{ll}\mathrm{Na}^{+} / \mathrm{K}^{+} \text {pumpIon transporter } & \text { Cell survival } \\
(\alpha 1 \text { subunit) } & \text { Cell } \\
& \text { proliferation } \\
\end{array}$} & $\begin{array}{l}\text { Human metastatic } \\
\text { melanoma (clinical } \\
\text { samples \& cell lines) }\end{array}$ & (Mathieu et al., 2009) \\
\hline TRPM8 & TRPC & Cell death & n.d. & $\begin{array}{l}\text { Human melanoma } \\
\text { (clinical samples \& } \\
\text { cell lines) }\end{array}$ & $\begin{array}{l}\text { (Yamamura et al., } \\
\text { 2008a) }\end{array}$ \\
\hline SK2/KCa2.2 & $K^{+}$channel & $\begin{array}{l}\text { Cell } \\
\text { proliferation } \\
\text { under hypoxia }\end{array}$ & yes & $\begin{array}{l}\text { Human melanoma } \\
\text { cell lines }\end{array}$ & $\begin{array}{l}\text { (Chantôme et al., 2009; } \\
\text { Meyer et al., 1999; } \\
\text { Tajima et al., 2006) }\end{array}$ \\
\hline EAG & $\mathrm{K}^{+}$channel & $\begin{array}{l}\text { Cell } \\
\text { proliferation }\end{array}$ & n.d. & Melanoma cell lines & $\begin{array}{l}\text { (Gavrilova-Ruch et al., } \\
\text { 2002; Meyer et al., 1999; } \\
\text { Pardo \& Suhmer, 2008) } \\
\end{array}$ \\
\hline$\overline{\mathrm{hERG}}$ & $\mathrm{K}^{+}$channel & $\begin{array}{l}\text { Cell } \\
\text { proliferation, } \\
\text { migration, } \\
\text { invasion }\end{array}$ & n.d. & $\begin{array}{l}\text { MDA-MB-435S cell } \\
\text { line }\end{array}$ & (Afrasiabi et al., 2010) \\
\hline SK3/KCa2.3 & $\mathrm{K}^{+}$channel & $\begin{array}{l}\text { Cell migration } \\
\text { and/or } \\
\text { invasion }\end{array}$ & no & $\begin{array}{l}\text { Human melanoma } \\
\text { cell lines }\end{array}$ & (Chantôme et al., 2009) \\
\hline KCa3.1/IKCa & $\mathrm{K}^{+}$channel & $\begin{array}{l}\text { Cell migration } \\
\text { and/or } \\
\text { invasion? }\end{array}$ & yes & $\begin{array}{l}\text { Human melanoma } \\
\text { cell lines }\end{array}$ & $\begin{array}{l}\text { (Schmidt et al., 2010; } \\
\text { Schwab et al., 1999) }\end{array}$ \\
\hline Nav1.6 & $\begin{array}{l}\text { Voltage gated } \\
\mathrm{Na}^{+} \text {channel }\end{array}$ & $\begin{array}{l}\text { Cell migration } \\
\text { and/or } \\
\text { invasion }\end{array}$ & n.d.. & $\begin{array}{l}\text { Human melanoma } \\
\text { (HTB-26) cell line }\end{array}$ & (Carrithers et al., 2009) \\
\hline$\overline{\mathrm{AQP1}}$ & Water channel & $\begin{array}{l}\text { Cell migration } \\
\text { and/or } \\
\text { invasion }\end{array}$ & n.d. & $\begin{array}{l}\text { Human (WM115) \& } \\
\text { murine (B16) } \\
\text { melanoma cell lines }\end{array}$ & $\begin{array}{l}\text { (Hu \& Verkman, 2006; } \\
\text { Monzani et al., 2009; } \\
\text { Saadoun et al., 2005) }\end{array}$ \\
\hline Cav 1.3(a) & $\begin{array}{l}\text { Voltage gated } \\
\mathrm{Ca}^{2+} \text { channel }\end{array}$ & $\begin{array}{l}\text { Cell migration } \\
\text { and/or } \\
\text { invasion }\end{array}$ & n.d. & $\begin{array}{l}\text { Human (A375M, } \\
\text { C8161) melanoma cell } \\
\text { lines }\end{array}$ & (Yohem et al., 1991) \\
\hline $\begin{array}{l}\text { Sigma-1 } \\
\text { receptor }\end{array}$ & $\begin{array}{l}\text { Chaperone } \\
\text { protein }\end{array}$ & Cell migration & & $\begin{array}{l}\text { Human melanoma } \\
\text { (clinical samples \& } \\
\text { cell lines) }\end{array}$ & $\begin{array}{l}\text { (Friebe et al., 2001; } \\
\text { Megalizzi et al., 2007) }\end{array}$ \\
\hline Kv1.3 & $\mathrm{K}^{+}$channel & Cell adherence & $n . d .$. & $\begin{array}{l}\text { Human melanoma } \\
(\mathrm{LOX}) \text { cell line }\end{array}$ & (Artym \& Petty, 2002) \\
\hline $\mathrm{Pkd} 2$ & $\begin{array}{l}\text { Non-selective } \\
\text { cation channel }\end{array}$ & Cell adherence & n.d. & $\begin{array}{l}\text { Murine melanoma } \\
\text { cell lines }\end{array}$ & (Bian et al., 2010) \\
\hline
\end{tabular}




\begin{tabular}{llllll}
\hline TASK-3 & $\begin{array}{l}\text { Two-pore } K^{+} \\
\text {channel }\end{array}$ & Unknown & yes & $\begin{array}{l}\text { Human melanoma } \\
\text { cell lines }\end{array}$ & $\begin{array}{l}\text { (Pocsai et al., 2006; } \\
\text { Rusznak et al., 2008) }\end{array}$ \\
\hline TRPM2 & TRPC & Unknown & no & Melanoma cell lines & (Orfanelli et al., 2008) \\
\hline TRPM1 & TRPC & Unknown & yes & $\begin{array}{l}\text { No in human } \\
\text { melanoma metastases }\end{array}$ & (Duncan et al., 1998) \\
\hline ENaC delta & $N a^{+}$channel & Unknown & n.d. & $\begin{array}{l}\text { Human melanoma } \\
\text { cell lines }\end{array}$ & (Yamamura et al., \\
\end{tabular}

(a) Expression of Cav 1.3 has been indirectly determined using Verapamil, a $\mathrm{Ca}^{2+}$ channel blocker. TRPC: Transient Receptor Potential Channel; n.d.: not determined

Table 1. Summary of ion channels expressed in melanoma

Our understanding of the action of channel proteins in cancer has just begun to take shape. Despite the advancements over the past two decades in defining the expression and the role of channel proteins in melanoma, many questions remain unanswered. For example, can a particular channel protein be a marker of a specific phenotype of melanoma? Is there particular intracellular signalling machinery involved for an ionic channel tumour function? As channel proteins are hijacked from their normal physiological function: Do channel proteins adopt a different folded conformation in a tumour context compared to a physiological context? Do channels form different protein complexes in a physiological context compared to tumour context? Regarding to these two last questions, do channel proteins link to a particular membrane tumour environment (e.g. lipid, raft)? Answering the last three questions will help design specific therapeutic approaches targeting channel proteins, that will make it possible to avoid side effects.

This review aims to identify the data of the literature that reported expression of proteins known to form ion channels and found to be expressed by cutaneous melanoma cells, and, whenever possible, to precise the biological function that has been assigned to them in this tumour context. A critical analysis on the druggable nature of these channel proteins will be presented. The cutaneous malignant melanoma being one of the cancers that has a greater metastatic potential, we shall pay a particular attention to the channels participating in the motility (migration and invasion) of the cancer cell. With the development of personalized targeted therapies, we are entitled to wonder if each channel protein, hijacked from its physiological function by the cancer cell, can indeed be considered as relevant therapeutic targets.

\section{Ion channels and cell survival and apoptosis}

\subsection{Store-operated channels (SOCs)}

Malignant melanoma is characterized by its extreme resistance to cell death-inducing factor (Becker et al., 2006; Soengas \& Lowe, 2003). The molecular derangement underlying the low susceptibility of melanoma cells to apoptosis include an aberrant activation of protein kinase $\mathrm{PKB} /$ Akt. Indeed, high resting PKB activity in the murine metastatic melanoma clone B16BL6, promotes their serum independent growth and protects these cells from apoptosis (Assa-Kunik et al., 2003). In contrast, non-tumour cells are sensitive to cell death-inducing factors associated to a very low basal activity of PKB (Assa-Kunik et al., 2003). Elevated level of PKB activity is a common finding in lesions of advanced melanoma (Dai et al., 2005; Slipicevic et al., 2005) and inversely correlates with patient survival (Dai et al., 2005). One of the activation pathways of PKB involves the complex calcium $\left(\mathrm{Ca}^{2+}\right) /$ calmodulin associated 
(Dong et al., 2007) with functional Store-Operated Channels (SOCs) (Fedida-Metula et al., 2008). In most non-excitable, cells depletion of endoplasmic reticulum (ER) stores elicits sustained $\mathrm{Ca}^{2+}$ influx by SOCs in plasma membrane, defining the major $\mathrm{Ca}^{2+}$ influx pathway (Putney, 1986). Following ER depletion, the ER $\mathrm{Ca}^{2+}$ sensor Stim1 forms multimers and migrates to ER/plasma membrane junctions where they activate a non-voltage-gated channel called $\mathrm{Ca}^{2+}$ release-activated $\mathrm{Ca}^{2+}$ (CRAC) channel, Orai. The CRAC current is characterized by a very low single channel conductance, a high $\mathrm{Ca}^{2+}$ selectivity, an inward rectification and a complex regulation by both intra and extracellular $\mathrm{Ca}^{2+}$ (Parekh \& Putney, 2005).

$\mathrm{Ca}^{2+}$ storage inside the ER is an essential indicator of the cell's proliferative, metabolic and apoptotic status. The retrograde signalling process from $\mathrm{ER} \mathrm{Ca}^{2+}$ depletion to store-operated $\mathrm{Ca}^{2+}$ entry (SOCE) activation has a central role for many cellular and physiological functions (Lewis, 2001). Thus, coordinated regulatory mechanisms must exist in the cell to ensure tight control of SOCs function. Among all key regulators of intracellular $\mathrm{Ca}^{2+}$ homeostasis, transmitochondrial $\mathrm{Ca}^{2+}$ transport is one of the most important, particularly in the subplasmalemmal and ER (Demaurex et al., 2009; Parekh, 2008) thanks to the mitochondrial uniporter (mCU) (Demaurex et al., 2009; Parekh, 2008; Rizzuto \& Pozzan, 2006). In addition to regulate $\mathrm{Ca}^{2+}$ homeostasis in these micro-domains, the ability of mitochondria to take up and release $\mathrm{Ca}^{2+}$ impacts on SOCE process (Glitsch et al., 2002). More clearly, mitochondria have been shown to modulate SOCE by buffering incoming $\mathrm{Ca}^{2+}$, so this dissipation of high $\mathrm{Ca}^{2+}$ micro domains is critical for sustained $\mathrm{Ca}^{2+}$ entry (Demaurex et al., 2009; Gilabert et al., 2001; Gilabert \& Parekh, 2000; Malli et al., 2003; Parekh, 2003, 2008). In order for mitochondria to buffer efficiently $\mathrm{Ca}^{2+}$ and to prevent the slow $\mathrm{Ca}^{2+}$-dependant inactivation, it was proposed $\mathrm{Ca}^{2+}$ entry attracts mitochondria to plasma membrane, close to the $\mathrm{Ca}^{2+}$ entry channel (Quintana et al., 2006; Varadi et al., 2004).

Recent study on melanoma cells, suggests a functional relevance for $\mathrm{Ca}^{2+}$ driven growth and survival-promoting signalling in these tumour cells due to a control of SOCE by mitochondria (Feldman et al., 2010). The authors have shown that coupling of mitochondria to SOCE sustains constitutive activation of PKB/Akt pathway leading to increase melanoma cells survival (Fig. 1). When they compared SOCE in malignant melanoma cells B16BL6-8 and in non-malignant cells Kb30 B16BL6, they described, only for malignant melanoma cells, a robust SOC function (without over-expression of Orai1 and Stim1) associated with accelerated trans-mitochondrial $\mathrm{Ca}^{2+}$ flux (Feldman et al., 2010). Conversely, inhibition of the trans-mitochondrial $\mathrm{Ca}^{2+}$ by the antagonist of $\mathrm{Na}^{+} / \mathrm{Ca}^{2+}$ exchanger (NCX) decreased SOCE (Feldman et al., 2010). This functional coupling allow the maintain of a strong $\mathrm{Ca}^{2+}$ fluxes in malignant melanoma cells. $\mathrm{Ca}^{2+}$ is, among others, an essential second messenger modulating AKT activity in many types of cells (Deb et al., 2004; Dong et al., 2007; Sandoval et al., 2007). AKT kinases, have emerged as critical mediators of signal transduction pathways downstream of activated tyrosine kinases and phosphatidylinositol 3-kinase. AKT protein is a cardinal node in diverse signalling cascades important in both normal cellular physiology and various disease states include cell proliferation and survival, intermediary metabolism, angiogenesis, and tissue invasion. Aberrant regulation of these processes result in cellular perturbations considered hallmarks of cancer, and numerous studies testify to the frequent hyperactivation of AKT signalling in many human cancers (Altomare \& Testa, 2005; Bellacosa et al., 2004; Testa \& Tsichlis, 2005). Recent studies have observed that $\mathrm{Ca}^{2+} /$ calmodulin may be a regulator of AKT activation and found that activity and functions of AKT are directly regulated by the $\mathrm{Ca}^{2+}$ signal (Fig. 1). More precisely, in 
neutrophils, it has been described that SOCE mediates intracellular alkalinization and ERK1/2, AKT phosphorylation (pAKT) (Sandoval et al., 2007). This link was supported by the correlation between of trans-mitochondrial $\mathrm{Ca}^{2+}$ flux triggered by SOCs and SOCE itself and levels of AKT in malignant $v$ s non-tumour melanoma cells (Feldman et al., 2010). Indeed, the high basal AKT activity in malignant melanoma cells is $\mathrm{Ca}^{2+}$ dependant and can be reversed by decreasing cytosolic $\mathrm{Ca}^{2+}$ concentration with $\mathrm{Ca}^{2+}$ chelator (Fedida-Metula et al., 2008) giving a special importance of SOCE in the control of intracellular $\mathrm{Ca}^{2+}$ concentration. Thus, down-regulation of the SOCs regulator Stim1 by shRNA leading to ten-fold reduction of SOCE correlated to a significantly decreased of pAKT levels compared to control transfected cells (Feldman et al., 2010). The same results have been obtained in melanoma tumour cells treated with an antagonist of $\mathrm{Na}^{+} / \mathrm{Ca}^{2+}$ exchanger: AKT inactivation and the decreased of intracellular $\mathrm{Ca}^{2+}$ concentration coincided with an important SOCE reduction (Feldman et al., 2010). Taken together, theses studies showed a real control of AKT regulation by a positive feedback loop between trans-mitochondrial $\mathrm{Ca}^{2+}$ transport and SOCE leading to strong cell resistance to apoptosis.

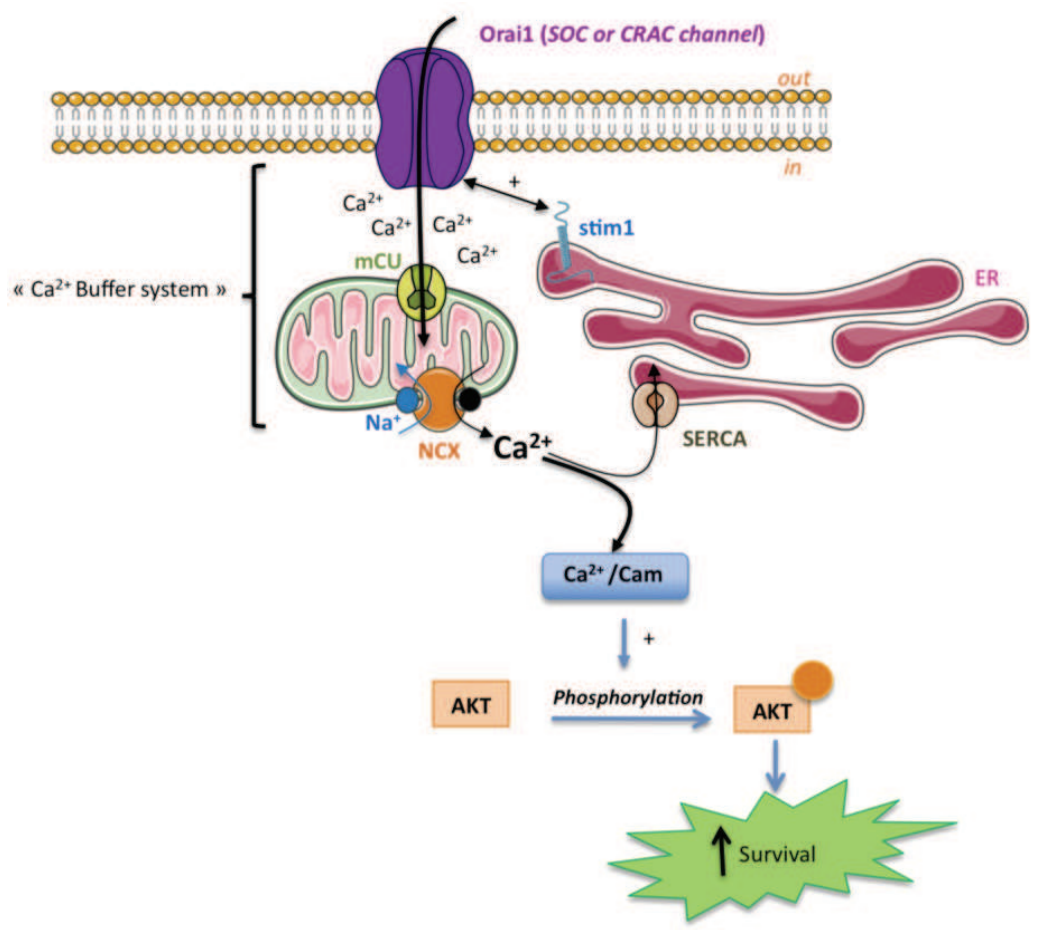

Fig. 1. AKT activation by mitochondria coupled to store-operated $\mathrm{Ca}^{2+}$ entry. Massive $\mathrm{Ca}^{2+}$ entry, following activation of Orai1 by Stim1, facilitates the transmitochondrial $\mathrm{Ca}^{2+}$ flux trough the uniporter $\mathrm{mCU}$ and exchanger $\mathrm{Na}^{+} / \mathrm{Ca}^{2+} \mathrm{NCX}$. This mechanism removes high $\mathrm{Ca}^{2+}$ level from the SOCs vinicity (as a $\mathrm{Ca}^{2+}$ buffer) and preventing the $\mathrm{Ca}^{2+}$ dependent slow inactivation of CRAC channel. The ability of mitochondria to buffer sub-plasmalemmal $\mathrm{Ca}^{2+}$ sustains a robust $\mathrm{Ca}^{2+}$ entry required for AKT activation leading to increase cell survival 
The role of SOCE and trans-mitochondrial $\mathrm{Ca}^{2+}$ transport present a real potential to develop new strategy to control AKT regulation and thus try to modulate tumour aggressiveness and death signals in cancer cells. It remains to show that these interesting and promising data, which have all been observed in murine cell lines, have a meaning in human melanomas.

\subsection{ATP-gated ionotropic $\mathrm{P} 2 \mathrm{X} 7$ receptor}

Purine nucleotides, essential components of DNA and RNA, are key elements in replication and transcription phenomenon and therefore in cell physiology and proliferation. Among all purine nucleotides, Adenosine 5'-Triphosphate (ATP) is also recognized as being the fundamental energetic source necessary for all cellular functions. Indeed ATP is a central and a precious intracellular molecule to be kept inside the cells. After having been confronted to considerable scepticism, Geoffrey Burnstock established the existence of intercellular purines signalisations pathways allowed by the release of ATP in the extracellular compartment (Burnstock, 1972). Indeed, extracellular purines are known to modulate general cellular properties such as cell survival and proliferation, cell differentiation and motility through the activation of plasma membrane purinergic receptors. These receptors are well known in vertebrates (Burnstock, 2006) and are conserved throughout the evolution in lower organisms such as unicellular eukaryotes (Fountain et al., 2007), green algae (Fountain et al., 2008), and also in plants (Kim et al., 2006; Weerasinghe et al., 2009).

Extracellular ATP activates plasma membrane G protein-coupled P2Y receptors and/or ligand-gated cation-permeable channels $\left(\mathrm{Na}^{+} / \mathrm{Ca}^{2+} / \mathrm{K}^{+}\right) \mathrm{P} 2 \mathrm{X}$ receptors (Burnstock, 2006). Among the members of the P2X receptors family, the latest cloned P2X7 receptor (P2X7R) (Rassendren et al., 1997; Surprenant et al., 1996) is very unique in its functioning by many features, such as 1) its low sensitivity to ATP (North, 2002), 2) its increasing activity, called facilitation, under successive or sustained applications of agonist (Roger et al., 2010; Roger et al., 2008), and 3) the appearance of a large, non-selective membrane pore after sustained stimulations with ATP due to the P2X7-dependent activation of pannexin-1 (Pelegrin \& Surprenant, 2006). From a physiological point of view P2X7R is expressed in cells from immune lineage and its activation by extracellular ATP at concentrations upper than $100 \mu \mathrm{M}$ is considered as an alarming signal, and is a key step in the initiation of the inflammatory cascade through the NLP3 inflammasome (Di Virgilio, 2007; Pelegrin, 2008). Pharmacological activation of P2X7R is generally associated to membrane permeabilization and blebbing, phosphatidyl serine loss of asymmetry, cell swelling, increase of internal $\mathrm{Ca}^{2+}$, loss of mitochondrial potential. All these phenomenon were demonstrated to be reversible under brief P2X7R activation, and called pseudoapoptosis, but were leading to cell death when prolonged stimulation (Mackenzie et al., 2005). This led to the hypothesis that P2X7R were cytolytic and that their stimulation or overexpression could be deleterious for cells (Di Virgilio et al., 1998; Mackenzie et al., 2005; Surprenant et al., 1996). Surprisingly, it was found that P2X7R was expressed at very high levels in several tumours, compared to normal tissues (Adinolfi et al., 2002; Raffaghello et al., 2006; Slater et al., 2004a; Slater et al., 2004b; Solini et al., 2008; Wang et al., 2004; Zhang et al., 2004) and was even proposed to represent an early prostate cancer marker (Slater et al., 2005), while in cervical cancer a decreased expression of P2X7R in cancer cells was reported ( $\mathrm{Li}$ et al., 2006). Several studies indicated the overexpression of P2X7R in human (Bringmann et al., 2001; Deli et al., 2007; Slater et al., 
2003; White et al., 2005) and B16 mouse melanoma (Ohshima et al., 2010). However the role of such a receptor in melanoma cell biology remains unclear.

The most accepted view attributes pro-apoptotic effects of P2X7R stimulation in melanoma and non-melanoma skin cancers (Greig et al., 2003; White et al., 2005). This supported the use of ATP for the treatment of melanoma (White et al., 2005; White et al., 2009), as it was proposed in the 1980's for other cancers (Rapaport, 1983, 1988; Rapaport et al., 1983). Ohshima and coll. (Ohshima et al., 2010) showed that P2X7R is expressed in a B16 mouse model of melanoma and was responsible for ATP release from cancer cells induced by irradiation. They also suggested that this release of ATP in the extracellular compartment of tumours could play as a signalling molecule between cancer cells and adjacent parenchymal cells. This should be further investigated.

In another study, P2X7R was reported to be overexpressed and functional in melanoma cells compared to normal melanocytes in which it was non-functional. In melanoma, P2X7R was associated to the overexpression of type 2 ryanodine receptor (RyR2) and contrarily to the general consensus; it displayed anti-apoptotic effects (Deli et al., 2007). The same study showed P2X7R proteins expression in melanoma cell nucleus. Therefore this raises the possibility that activation of P2X7R in melanoma could be responsible for different cell fate, depending on its subcellular localization and/or protein association. It is also possible that P2X7R proteins may be dysfunctional in some cases as it was proposed in chronic lymphocytic leukaemia with the overexpression of the loss-of-function mutant allele A1513C (Wiley et al., 2002) or in cervical cancers in which P2X7R is overexpressed under its truncated form that is inefficient to permeabilise cell membrane (Feng et al., 2006a; Feng et al., 2006b).

All these studies mainly focused on the regulation of cell proliferation / apoptosis and P2X7R participation in other parameters such as cancer cell invasiveness have not yet been assessed in melanoma. A recent study performed in MDA-MB-435s cancer cells showed the expression of the full length and fully functional P2X7R and that its activation was leading to the SK3-dependent increase in cell motility, probably through the increase of internal $\mathrm{Ca}^{2+}$, and was dramatically increasing extracellular matrix proteolysis through the release of active cystein cathepsins (Jelassi et al., 2011). Indeed further studies will be necessary to really establish the role of such intriguing receptors in melanoma as well as in other cancer types. Depending on this, either the use of agonists, or recent antagonists, mainly developed for the treatment of inflammatory diseases (Romagnoli et al., 2008) could be considered for the treatment of melanoma.

\subsection{Calcium channel TRPM8}

The TRPM8 (express transient receptor potential melastatin subfamily member 8 ) channel, a cold-temperature receptor, belongs to the transient receptor potential (TRP) channel superfamily. It has been identified in sensory neuron as a $\mathrm{Ca}^{2+}$-permeable cation channel that is stimulated by temperatures below $28^{\circ} \mathrm{C}$ and is modulated in a voltage channeldependent fashion. After activation by temperature decrease or cooling compounds such as menthol or eucalyptol, TRPM8 induces membrane depolarization by $\mathrm{Ca}^{2+}$ influx. In addition to transduction of thermal stimuli in the peripheral nervous system, TRPM8 serves other biological roles according to its expression in other tissues (e.g. bladder, male genital tract) (Stein et al., 2004). It is also observed that TRPM8 expression increases dramatically in many cancer types including cutaneous melanoma (Yamamura et al., 2008a). Yamamura and coll. demonstrated that TRPM8 activation by agonists suppresses human melanoma cell viability 
(Yamamura et al., 2008a). Interestingly, numerous classical TRPM8 agonists are known, in addition to novel agonists (Bodding et al., 2007) that may be useful to treating most cancers in which TRPM8 channel is overexpressed in comparison to the corresponding normal tissue. Because of their inocuity, they represent a formidable pharmacological tool to evaluate this channel as target to melanoma therapy.

\subsection{The sodium pump ( $\mathrm{Na}^{+} / \mathrm{K}^{+}$-ATPase)}

The sodium pump $\left(\mathrm{Na}^{+}, \mathrm{K}^{+}\right.$-ATPase) is a plasma membrane binary complex with enzymatic activity that moves three $\mathrm{Na}^{+}$ions out of, and two $\mathrm{K}^{+}$ions into, the cell for each ATP that is hydrolysed. In humans, the $\mathrm{Na}^{+}$pump acts to maintain resting membrane potential, is useful as transporter, regulate intracellular ion homeostasis, and regulate cellular volume. The human sodium pump is composed of two essential protein subunits, the catalytic $\alpha$ subunit that has four isoforms $\left(\alpha_{1}-\alpha_{4}\right)$ and the auxiliary $\beta$-subunit that has three isoforms $\left(\beta_{1}-\beta_{3}\right)$ (Morth et al., 2011), and an optional regulatory $\gamma$-subunit with tissue-specific expression. The $\alpha_{1}$ and $\beta_{1}$ subunits of the $\mathrm{Na}^{+}, \mathrm{K}^{+}$-ATPase are ubiquitously expressed and form $\alpha_{1} \beta_{1}$ complex in most tissues, the other $\alpha$ and $\beta$ subunits exhibit a restricted pattern of expression specific to each subunit (Morth et al., 2011). Many cancer types over-express the different $\alpha$ sub-units, including melanoma (Boukerche et al., 2004). Interestingly, Mathieu and coll. have recently shown that more than $30 \%$ of all human melanomas, $50 \%$ of all melanoma metastases and $72 \%$ of brain melanoma metastases over-expressed sodium pump $\alpha_{1}$ subunit compared with only $5 \%$ of naevi. Interestingly the $\alpha_{1}$ subunit expression significantly correlates with tumour thickness and disease progression (Mathieu et al., 2009). Moreover, using the pharmacological drug UNBS1450 and genetic approach, the authors demonstrated that functional inhibition of $\alpha_{1}$ subunit in melanoma cell lines impaired cell growth, induced cell death, and improved the survival of immunodeficient mice bearing human melanoma brain metastases. Note that UNBS1450, a hemi-synthetic cardiotonic steroid, which binds to the $\alpha_{1}$ subunit of the sodium pump, has entered Phase I clinical trials in cancer patients.

\section{Ion channels and melanoma cell proliferation}

Information on ion channels involvement in melanoma cell proliferation is highly fragmented and unclear, although early data were published almost three decades. This research is still in its beginnings. Indeed there is good evidence that at least $\mathrm{K}^{+}$channels are involved in the cell cycle progression and proliferation in many cancer cells of different origins (Villalonga et al., 2007). Several hypotheses could explain the involvement of $\mathrm{K}^{+}$ efflux in the control of the cell cycle: $\mathrm{Ca}^{2+}$ signalling, membrane potential and cell volume (Villalonga et al., 2007). In melanoma cell lines, the inhibition of $\mathrm{K}^{+}$channel activity by unspecific $\mathrm{K}^{+}$channel blockers leads to membrane depolarization and an arrest of cell proliferation (Gavrilova-Ruch et al., 2002; Lepple-Wienhues et al., 1996; Nilius \& Wohlrab, 1992). In addition, membrane depolarization of melanoma cells induced by elevated extracellular $\mathrm{K}^{+}$concentration inhibited proliferation of cycling cells (Nilius \& Wohlrab, 1992). Nilius et al. (Nilius et al., 1993), proposed that in human melanoma cells overexpression of $\mathrm{K}^{+}$channels leads to hyperpolarisation as a result of the efflux of cations from the cell interior, which subsequently causes inward movement of $\mathrm{Ca}^{2+}$ ions to maintain the membrane potential. The role of $\mathrm{Ca}^{2+}$ in the transition from the $\mathrm{G} 1$ to the $\mathrm{S}$ phase during 
mitosis in mammalian cells is well documented and $\mathrm{Ca}^{2+}$ acts as a pacemaker that initiates the timing of cell cycle transitions (Santella et al., 2005). Interestingly, recent evidence suggests that in addition to their $\mathrm{K}^{+}$conductance, a non-pore function of KCa3.1/SK4/IKCa and Eag1 could be observed by interacting directly with cell signalling network involved in the control of cell proliferation in non-cancer cells (Hegle et al., 2006; Millership et al., 2010). Furthermore, mutation that eliminates Eag1 ion permeation fails to completely abolish xenograft tumour formation, indicating that Eag1 contributes to tumour progression independently of its primary function as an ion channel (Downie et al., 2008).

\subsection{Small and intermediate calcium-activated potassium channel (SKCa and IKCa)}

The calcium-activated $\mathrm{K}^{+}$channel KCa family encompasses Small- (SKCa) and Intermediate(IKCa/KCa3.1/SK4) conductance calcium activated $\mathrm{K}^{+}$channels. Functional SKCa channels result mostly in a homo or heteromeric assemblies of four subunits. There are three isoforms of SKCa subunits, named SK1/KCa2.1, SK2/KCa2.2, SK3/KCa2.3, which associate to form homo- or hetero-tetramers (Ishii et al., 1997; Monaghan et al., 2004). SK1, SK2 and SK3 proteins are principally expressed in central neurons where SKCa channels have a fundamental role in regulating neuronal excitability (Bond et al., 2005). Indeed, they hyperpolarize the plasma membrane and they contribute to the long lasting afterhyperpolarisation that follows an action potential (Bond et al., 2005). SK2 and SK3, in contrast to SK1, are not restricted to neuronal tissues and SK3 protein is expressed in vascular and visceral smooth muscle-rich tissues (Chen et al., 2004). In these muscles the activation of SK3 channel induces hyperpolarisation that respectively regulates muscle tone and cell motility (Chen et al., 2004; Herrera et al., 2003; Taylor et al., 2003). This membrane function of SK3 channel, hyperpolarisation that is dependent of $\mathrm{K}^{+}$flux, is that you except to find for $\mathrm{K}^{+}$channels in excitable cells like muscle and neuronal cells.

SKCa channel activity is independent to voltage but sensitive to elevated $\mathrm{Ca}^{2+}$ concentrations. Involvement of theses channels have been investigated in melanoma cells because their resulting $\mathrm{K}^{+}$efflux could provide a membrane hyperpolarisation necessary to cell proliferation. In agreement with the reported restricted expression pattern of SK1 channel mainly found in neuronal tissues, transcript was no detected in melanoma cells and in normal human epidermal melanocytes NHEM (Chantôme et al., 2009; Tajima et al., 2006). In contrast, SK2 transcripts were always detected in melanocyte and melanoma cell lines but electrophysiological analyses revealed that SK2 channels were not functional in the three melanoma cell lines tested (IGR-1, SKmel-28 and 518A2) (Chantôme et al., 2009; Meyer et al., 1999; Tajima et al., 2006). Interestingly, SK2 transcripts level and KCa (SK2 et KCa3.1) currents are increase under hypoxia and only in this condition, apamin application, a non specific pore blocker of SK2, reduced cell proliferation rates in IGR-1 melanoma cells (Tajima et al., 2006). SK3 transcripts and functional SK3 channels have been found in several melanoma cells but not in untransformed melanocytes (Chantôme et al., 2009; Tajima et al., 2006). It has been clearly demonstrated that SK3-dependent efflux regulates membrane potential in 518A2 and SKmel-28 melanoma cells (Chantôme et al., 2009). However, enforced production of SK3 channels in SK3 non-expressing melanoma cells or specific SK3 channel extinction in 518A2 melanoma cells has no effect on their cell proliferation (Chantôme et al., 2009).

At last, KCa3.1/SK4 channels are widely expressed in a variety of non-excitable tissue and have been involved in cell cycle progression of different type of cancer cells such as breast, 
pancreatic, and endometrial cancer cells (Jager et al., 2004; Ouadid-Ahidouch et al., 2004; Wang et al., 2007). KCa3.1/SK4 transcripts are detected in NHEM and in all melanoma cell lines tested and electrophysiological analyses shown strong KCa3.1/SK4 currents (Chantôme et al., 2009; Meyer et al., 1999; Tajima et al., 2006). Application of charybdotoxin, an unspecific KCa3.1/SK4 blocker, inhibits or not cell proliferation of IGR-1 cells according to studies (Gavrilova-Ruch et al., 2002; Tajima et al., 2006). A more recent study using TRAM-34, a specific inhibitor of KCa3.1/SK4 channel (Wulff et al., 2000), demonstrated that this channel is not involved in cell proliferation of SKmel-28 melanoma cells despite actively regulated membrane polarization (Chantôme et al., 2009). Note that, TRAM-34 inhibits both $\mathrm{K}^{+}$conductance and non-pore function of KCa3.1/SK4 channels (Millership et al., 2010). In conclusion, even if membrane polarization is in part controlled by SK3 and KCa3.1/SK4 efflux in melanoma cell lines, it seems not involved or not sufficient to modulate their cell proliferation. It will be interesting to precise the mechanism through SK2 under hypoxia condition promotes cell proliferation of melanoma cells.

\subsection{Voltage-gated potassium channels and Eag1}

Voltage gated $\mathrm{K}^{+}$channels (VGKC) represent the largest ion channel family. Functional channels result from the association of alpha- (pore) and beta- (accessory) subunits (Pongs \& Schwarz, 2010). Alpha subunits co-assemble in tetramers, each subunit containing a "voltage-sensor" determining the voltage threshold for channel activation. VGKC are divided up in 12 families containing up to 8 members, totalizing 40 different cloned alpha subunit isoforms (Gutman et al., 2003). Functional channels result from the association of different members inside a given family, giving rise to an extraordinary large panel of different channels with various gating kinetics and pharmacological properties. The set of alpha subunit expressed by a given cell type defines in fact its electrical signature and its function. VGKC are widely expressed in excitable and non-excitable cells and participate to the control of membrane resting potential and action potential repolarisation and firing frequency. Not surprisingly, these channels are involved in a large variety of physiological processes including neuronal excitability, hormone secretion, muscle contraction, and cardiac rhythm. Interestingly, several VGKC are abnormally expressed in cancer versus healthy tissues, including melanoma. Their initial function is then hijacked to participate to the tumour phenotype. We will more particularly focus on Eag1 and its putative role in cell proliferation, and hERG and Kv1.3 and their putative role in cell migration / invasion (see below).

Eag1 (ether-à go-go) channel also known as KCNH1 (gene) or Kv10.1 (protein) are a voltagegated channel that regulates permeation of ion in response to changes in the membrane potential. Eag1 gives rise to a slowly activating and non-inactivating current in heterologous expression systems. Eag1 is mainly expressed in the brain \{Martin, 2008 \#283; (Martin et al., 2010). In the periphery, Eag1 expression is restricted to cell populations of the gastrointestinal tract, pancreas and male reproductive system (Hemmerlein et al., 2006; Pardo \& Suhmer, 2008).

No information about its expression in melanocyte has been reported. While its function in the brain remains unknown, Eag1 has been involved in skeletal muscle development, the channel being transiently expressed in the onset of myoblasts fusion (Bijlenga et al., 1998). Remarkably, Eag1 is associated with tumours development in patients and animals. Eag1 is significantly overexpressed in up to $70 \%$ of tumour samples and cell lines (Hemmerlein et 
al., 2006; Pardo et al., 1999; Pardo \& Suhmer, 2008), including melanoma cells (Meyer et al., 1999). The mechanisms inducing Eag1 overexpression in cancer cells is still unknown, but it has been reported that immortalization of cells by oncogenes such as papillomavirus provokes Eag1 expression (Diaz et al., 2009). The molecular and functional links between Eag1 expression and cancer development has been intensively scrutinized. Eag1 inhibition by either siRNA silencing or functional antibodies decreases cancer cell proliferation in vitro (Weber et al., 2006) and in vivo (Gomez-Varela et al., 2007). Moreover, Eag1 expression increases neovascularisation and enhances cell resistance to hypoxia by increasing Hif activity (Downie et al., 2008). Interestingly, point mutation abolishing Eag1 pore function failed to completely abolish xenograft tumour formation by transfected cells, indicating that Eag1 contributes to tumour progression independently of its primary function as an ion channel. Other study proposes that Eag-1 channels participate to cell-cycle progression in IGR-1 melanoma cells by using different unspecific blockers of $\mathrm{K}^{+}$channels (Gavrilova-Ruch et al., 2002). It will be interesting to confirm this result by using specific siRNA directed to Eag1 channels as it was already used previously in other type of cancer cell lines (Weber et al., 2006). Altogether, these data suggest that Eag1 represent a very promising target in melanoma treatment. It is noteworthy that Eag- 1 is not expressed in the heart, rendering possible the use of specific Eag-1 blockers. However good selectivity vs the hERG cardiac channel, of the same family, (KCNH2) should be taken into account. In this perspective, functional antibodies would represented an interesting perspective to target Eag-1 in tumours, neither altering the cardiac hERG channel, nor the Eag-1 channels expressed in the CNS because of the brain blood barrier (Gomez-Varela et al., 2007).

\section{Ion channels and melanoma cell migration / invasion / adhesion}

With the occurrence of metastasis, the prognosis of melanoma is poor, with limited available treatments and an expected survival less than one year. Knowing that the metastasis occurrence involves many cellular processes including cell deformation, invasion, migration, adhesion and homing in the "metastatic" site, it is important to define the specific molecular mechanisms governing each of these various steps. This is especially important that no new treatment of metastatic melanoma has been validated for decades. Intensive research in this area has identified at least a type of ion channels involved in melanoma cell migration, the calcium-activated potassium channel SK3, and channels that contributes to melanoma cell migration / invasion / adhesion.

\subsection{SK3 channel}

Among SKCa channels, SK3 channel was found to promote breast and colon epithelial cancer cells and, melanoma cells migration by hyperpolarizing plasma cell membrane (Chantôme et al., 2009; Potier et al., 2006; Potier et al., 2010). As mentioned above, SK3 protein is produced in melanoma cells but not in untransformed melanocytes (Chantôme et al., 2009). This is not surprising if you consider that melanocytes share a neural crest origin with most SK3-expressing mature cells, i.e. neurons, glial cells and endocrine cells. Reexpression of embryonic genes during cancer has been widely described (Monk \& Holding, 2001). It is therefore plausible that SK3 channel expression during melanoma malignancy corresponds to the re-expression of an embryonic gene expressed by a neural progenitor common to neurons and melanocytes (Klein et al., 2007; Rasheed et al., 2005). 
We have reported that SK3 channel promotes melanoma cell migration by hyperpolarisating plasma membrane as observe in excitable cells (Chantôme et al., 2009). This new function of the SK3 channel in melanoma cells was revealed using pharmacological and molecular biology approaches (there is no specific inhibitor of SK3 channel); stable silencing SK3 protein inhibited melanoma cell migration, which became insensitive to apamin and inversely, a stable expression of SK3 in SK3-non expressing melanoma cells, enhanced their migration that became sensitive to apamin. If patch-clamp experiments reveal that SK3 channel hyperpolarises plasma membrane of melanoma cells, increasing external $\mathrm{K}^{+}$ concentration reduced only SK3-dependant cell motility (Chantôme et al., 2009). All of these experiments demonstrate that SK3 channel promotes melanoma cell migration through its primary function as an ion channel. Since the KCa3.1 channel had no effect on melanoma cell migration despite actively regulating membrane potential we propose that the increase of melanoma cell migration by hyperpolarisation is SK3 dependent.

The mechanism by which SK3 channel regulates melanoma cell migration may involve $\left[\mathrm{Ca}^{2+}\right]$ oscillations (frequency, amplitude) regulation (Fig. 2). Indeed, an increase of $\mathrm{K}^{+}$efflux shifts the membrane potential towards negative values (hyperpolarization) and consequently increases the $\mathrm{Ca}^{2+}$ driving force (Potier et al., 2006; Rao et al., 2006; Rao et al., 2002). Inversely, a reduction of SK3 channel activity may depolarize the plasma membrane and reduce $\mathrm{Ca}^{2+}$ entry. That further suggests that SK3 channel interacts in cooperation with a specific complex such as voltage-independent-calcium channel like transient-receptor potential (TRP) that are known to be sufficient to activate $\mathrm{Ca}^{2+}$-regulated stimulatory pathways for cell migration (Louis et al., 2008; Rao et al., 2006; Waning et al., 2007; Wondergem et al., 2008). This needs to be elucidated.

The ability of SK3 channel to promote cancer cell migration led us to create a patent that addresses the use of this protein as a tool for the in vitro screening of compounds that inhibits SK3-dependent cell migration and metastasis development (Potier et al., 2008).

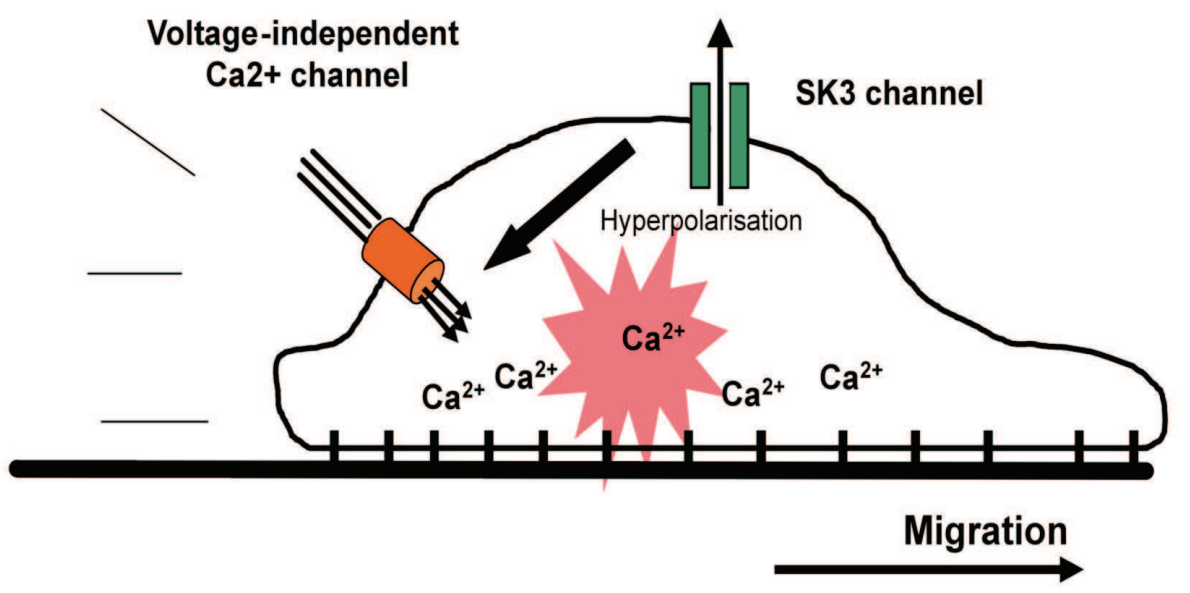

Fig. 2. Proposed model to explain how SK3 channel increase melanoma cell migration. The expression of SK3 protein lead to a functional SK3 channel that hyperpolarizes plasma membrane and increase $\mathrm{Ca}^{2+}$ entry through voltage-independent $\mathrm{Ca}^{2+}$ channels and intracellular $\mathrm{Ca}^{2+}$ concentration promoting cell migration 


\subsection{IKCa/KCa3.1/SK4 channel}

The KCa3.1 channel - composed of protein that is strictly expressed outside the central nervous system - is expressed in melanocytes and melanoma cell lines (Allen et al., 1997; Chantôme et al., 2009; Schmidt et al., 2010; Schwab et al., 1999; Tajima et al., 2006). This channel appears to be involved in the migration process by facilitating the retraction of the rear part of migrating cells through induction of local cell shrinkage (Schwab, 2001). Interestingly, the KCa3.1 channel was found to support melanoma inhibitory activity, a protein known to play a role in melanoma development, progression and metastasis formation (Schmidt et al., 2010). KCa3.1 channel was also found to be involved in noncancerous cell migration o (e.g. lung mast cells or human coronary smooth muscle cells) (Cruse et al., 2006; Toyama et al., 2008). Low dose of TRAM-34 (that specifically blocks KCa3.1 channel and depolarize cell membrane) and high dose of TRAM-34 or clotrimazole (that inhibit KCa3.1 channels and other voltage dependent $\mathrm{K}^{+}$channels (Wulff et al., 2000)) did not impair melanoma cell migration (Chantôme et al., 2009). This indicates that KCa3.1 channel activity has no effect on melanoma cell migration despite its active role in regulating membrane potential.

\subsection{Voltage-gated potassium channel hERG}

The human ether-à-go-go (eag) related gene channel hERG, also known as KCNH2 (gene) and Kv11.1 (protein), is a member of the related Eag-like family of $\mathrm{K}^{+}$channel. hERG encodes a voltage-dependent $\mathrm{K}^{+}$channel that normally regulates cardiac repolarisation (Sanguinetti et al., 1995; Trudeau et al., 1995). The channel presents a unique activation kinetic: upon depolarisation, the channel opens but very rapidly inactivates, shutting down the $\mathrm{K}^{+}$efflux. During the repolarisation phase of cardiac action potential, the recovery from inactivation is faster than the deactivation, the resulting $\mathrm{K}^{+}$tail current shortening the action potential duration and decreasing the firing frequency (Schwarz \& Bauer, 2004). In contrast to Eag1, hERG channel is expressed in a variety of tissue but its expression in melanocyte has not been investigated in our knowledge, but it is found in many tumour cells of different origins and exert pleiotropic effects in cancer cells (Asher et al., 2010). In a series of recent studies, the team of Arcangeli has proposed hERG as a biological marker of leukaemia and several solid tumours and leukaemia. HERG is involved in cell proliferation, apoptosis resistance and cell invasion (Bianchi et al., 1998; Lastraioli et al., 2004; Pillozzi et al., 2002). Several hERG isoforms interacting to modulate subunit trafficking and functional channel membrane expression are linked to the cell cycle and the differentiation state of myeloid and neuroblastoma cells (Crociani et al., 2003; Guasti et al., 2008). Strikingly, hERG forms membrane macromolecular complexes with $\beta 1$ integrins and the growth factor receptor FLT1. Cell adhesion to extra cellular matrix components such as fibronectin activates hERG and enhances adhesion receptor signalling such as tyrosine phosphorylation of focal adhesion kinase (Cherubini et al., 2005). In AML, the hERG1b isoform is recruited by the $\beta 1$ integrin to promote FLT1 signalling. In vivo, hERG positive blasts are more efficient in invading the peripheral circulation and the extramedullary sites after engraftment into immunodeficient mice (Pillozzi et al., 2007). In acute lymphoblastic leukaemia, hERG expression enhances chemotherapy-induced apoptosis and drug resistance (Pillozzi et al., 2011). In the MDA-MD-435s cell line, hERG participates to cell migration and proliferation through a MAP kinase/c-fos pathway. HERG blockers such as E-4031 or silencing by siRNA reduce both proliferation and migration, but surprisingly no current can be recorded, demonstrating that hERG is no functional as a $\mathrm{K}^{+}$pore (Afrasiabi et al., 2010). Similar to 
Eag1, hERG might mediate at least in part, its effects on cell cancer behaviour through nonpore associated mechanisms. However, concerning the role of hERG in melanoma cell behaviour, data must be used cautiously since the cancer origin of MDA-MD-435s cell line is rather a basal-type breast cancer, even if MDA-MD-435s cells have a genetic basis similar to melanomas (Chambers, 2009; Rae et al., 2007; Sellappan et al., 2004).

\subsection{Voltage-gated potassium channel Kv1.3}

Kv1.3 (KCNA3) channels, another voltage-dependent $\mathrm{K}^{+}$channel, have been first isolated from Jurkat T cells (Chandy et al., 2004; DeCoursey et al., 1984). By regulating the resting membrane potential and thus the $\mathrm{Ca}^{2+}$ driving force, this channel modulates NFAT (Nuclear Factor of Activated T cells) translocation and mitogenesis (Chandy et al., 2004). The expression level of Kv1.3 is unchanged or down regulated depending the cancer type. In breast adenocarcinoma, the promoter of the gene encoding the channel is methylated leading to a down regulation of Kv1.3 expression (Bielanska et al., 2009; Brevet et al., 2009). In the LOX melanoma cell line, Kv1.3 is associated to the $\beta 1$-integrin subunit and might regulate tumour cell behaviour by influencing macro molecular complexes linked to integrins (Artym \& Petty, 2002). In this way, Kv1.3 may have in melanoma cells the same function as hERG in leukaemia cells.

\subsection{Voltage-gated sodium channel Nav1.6}

Voltage-gated $\mathrm{Na}+$ channels $(\mathrm{NaV})$ are known to be responsible for transient inward $\mathrm{Na}+$ currents in excitable cells in which they are responsible for the initial membrane depolarisation triggering and allowing the propagation of action potentials. They are blocked by the highly specific blocker tetrodotoxin (TTX) at different doses from nM to $\mu \mathrm{M}$ concentrations depending on isoforms and numerous pharmacological modulators of these channels have been developed by pharmaceutical companies for the treatment of pain or some cardiovascular diseases.

The expression and activity of pore-forming alpha subunits of $\mathrm{NaV}$ have been linked to cancer cell migration/invasion originating from different tissues such as prostate (Diss et al., 2001), breast (Fraser et al., 2005; Gillet et al., 2009; Roger et al., 2003), lung (Onganer \& Djamgoz, 2005; Roger et al., 2007), cervix (Diaz et al., 2007), colon (House et al., 2010), ovaries (Gao et al., 2010). Depending on the tissues, pore-forming isoforms responsible for the $\mathrm{Na}+$ current and for the cellular effect, i.e. the enhancement of cancer cell invasiveness are different, but appeared not to be linked to the triggering of action potentials, but rather to the cystein cathepsin-dependent extracellular matrix degradation (Gao et al., 2010). In human breast cancer cells MDA-MB-231, NaV1.5 functioning enhances the activity of the $\mathrm{Na}^{+} / \mathrm{H}^{+}$exchanger type 1 (NHE-1) responsible for the perimembrane space acidification and thus promoting cystein cathepsins proteolytic activity (Brisson et al., 2011).

In melanoma there are, to our knowledge, only two studies reporting the expression of $\mathrm{NaV}$. The first one was carried out in the late 1990's, on human melanoma cell lines, and had for goal to identify the electrophysiological characteristics of these cells (Allen et al., 1997). In this first article, TTX-sensitive $(\mathrm{Kd} \sim 6 \mathrm{nM})$ voltage-gated $\mathrm{Na}+$ currents were recorded in about $40 \%$ of C 8161 and C 8146 cells tested. However, the role of these currents in melanoma biology was not identified.

Later on, a study performed by Carrithers and coll. on HTB-26 invasive human melanoma cells indicated the expression of a splice variant lacking the exon 18 of the $\mathrm{Na}+$ channel SCN8A gene, encoding the NaV1.6 protein (Carrithers et al., 2009). The activity of this 
channel, mainly identified in intracellular vesicles, was found to be involved in melanoma invadopodia formation and cell invasiveness. This effect was proposed to depend on intracellular $\mathrm{Ca}^{2+}$ regulation through mitochondrial $\mathrm{Na}^{+} / \mathrm{Ca}^{2+}$ exchangers and to the rapid remodelling of F-actin cytoskeleton. This regulation of intracellular $\mathrm{Na}^{+}$and $\mathrm{Ca}^{2+}$ homeostasis could also modulate the activity of $\mathrm{pH}$ regulators, such as NHE-1, demonstrated to be key regulators of melanoma invasion at the front of invasive cells (Stock et al., 2007; Stock \& Schwab, 2009).

\section{Ion channel modulators as therapeutic targets}

\section{Sigma1 receptors as ion channel regulatory partners in cancer cells}

Targeting ion channels abnormally expressed in cancer cells represents an exciting new perspective for cancer treatment. Nevertheless, because these ion channels are also expressed in the heart or brain, the use of toxins is potentially hazardous and the therapeutic challenge is to specifically target ion channels in tumours. Characterizing the specific interactors of ion channels in cancer cells opens an interesting alternative strategy, providing the possibility to target ion channels through these tumour-specific partners (Arcangeli et al., 2009). The Sigma 1 receptor (Sig1R) is a $25 \mathrm{kDa}$ protein anchored to the different cell membrane systems including ER, mitochondria, nucleus and plasma membranes (Tsai et al., 2009). The structure shares no homology with other mammalian proteins (Hanner et al., 1996) and includes two putative transmembrane domains (Su et al., 2010). Sig1R is distributed in the brain and peripheral tissues such as liver, kidney, ovaries or testis. Sig1R binds a large panel of exogenous drugs such as antipsychotics, opioids, antidepressants (sigma ligands) but also interacts with endogenous steroids (cholesterol and progesterone). Since the introduction of the concept thirty years ago (Martin et al., 1976) the function associated to Sig1R, mainly studied through the effects produced by sigma ligands, has been representing a challenging question. Sig1R have been involved in a huge number very different functions covering nociception, memory, drug addiction, cell electrical activity, apoptosis, cell cycle or immune response. Despite the abundant literature generated so far, the primary molecular mechanism governed by Sig1R to achieve those different functions has been missing. Recently, Su \& Hayashi demonstrated in neuroblastoma cells that Sig1R physically associates to the chaperone Bip at the mitochondria-associated ER membrane (MAM) where it regulates $\mathrm{Ca}^{2+}$ fluxes between ER and mitochondria through the stabilisation of IP3 receptors (Fig. 3) (Hayashi \& Su, 2007). From these finding, the emerging concept of the Sig1R as an interorganelle signalling modulator activated either by ligands or cell stress was proposed (Su et al., 2010). On the other hand, Sig1R interacts with various molecular families of ion channels including Kv, Cav, Nav, VRCC, NMDA or Asic channels (Herrera et al., 2008; Johannessen et al., 2009; Renaudo et al., 2007; Renaudo et al., 2004; Soriani et al., 1999a; Soriani et al., 1999b; Soriani et al., 1998). Interestingly, sigma receptors are overexpressed in many cancer cell types and the protein is now considered as a tumour biomarker (Aydar et al., 2006; Aydar et al., 2004). Many efforts have been done since the early 90's to develop specific sigma ligands for medical imagery and therapeutic applications (Collier et al., 2007). In particular, amine-amide-dithiol-[99mTc]oxotechnetium(V) complexes have been proposed as in vivo diagnostic agents for melanoma and its metastasis, with a high tumour uptake and significant tumour/non-tumour ratio (Friebe et al., 2001). Recently, sigma ligands have been used to develop nanoparticles that can systemically deliver siRNA into the cytoplasm of B16F10 murine melanoma cells, which express the sigma receptor. The targeted 
nanoparticles containing c-Myc siRNA sensitized B16F10 cells to paclitaxel (Taxol), inducing a strong decrease in cell growth. Treatments of c-Myc siRNA in the targeted nanoparticles also showed significant inhibition on the growth of MDA-MB-435 tumour (Chen et al., 2010). Last, the sigma1 ligand 4-IBP decreases melanoma cell migration in vitro (Megalizzi et al., 2007). These data raise the question of the function of sigma receptors in cancer cells. Recently, we have demonstrated that sigma ligands inhibit cell cycle by inhibiting both $\mathrm{Kv}$ and volume regulated chloride channels (VRCC) in leukaemia and small cell lung carcinoma cells. The alteration of these ion channels by sigma ligand provokes a reduced capacity of cell to regulate their shape and volume during at the G1/S checkpoint, leading to an accumulation of p27kip1 and the downstream reduction in cyclin A levels (Renaudo et al., 2004; Renaudo et al., 2007). Moreover, we found that the overexpression of Sig1R in cancer cells enhanced per se apoptosis resistance by reducing VRCC activation kinetics, this channel controlling the apoptosis volume decrease (Renaudo et al., 2007). These finding suggest that sigma1 receptors are involved in the control of cell shape through $\mathrm{K}^{+}, \mathrm{Cl}^{-}$and water fluxes, a key factor for cancer cell division, apoptosis and migration (Habela et al., 2009; Rouzaire-Dubois et al., 2000). Interestingly, Su and coll. have shown that Sig1R regulate IP3 receptors following a cell stress (Tsai et al., 2009). It can then be suggested that the ion channel regulatory function of Sig1R is specifically potentiated in cancer cells when compared to healthy cells. However, if the effects of exogenous sigma receptor ligands on several ion channels are well described, the innate role of Sig1R regarding ion channel function or expression needs to be studied.

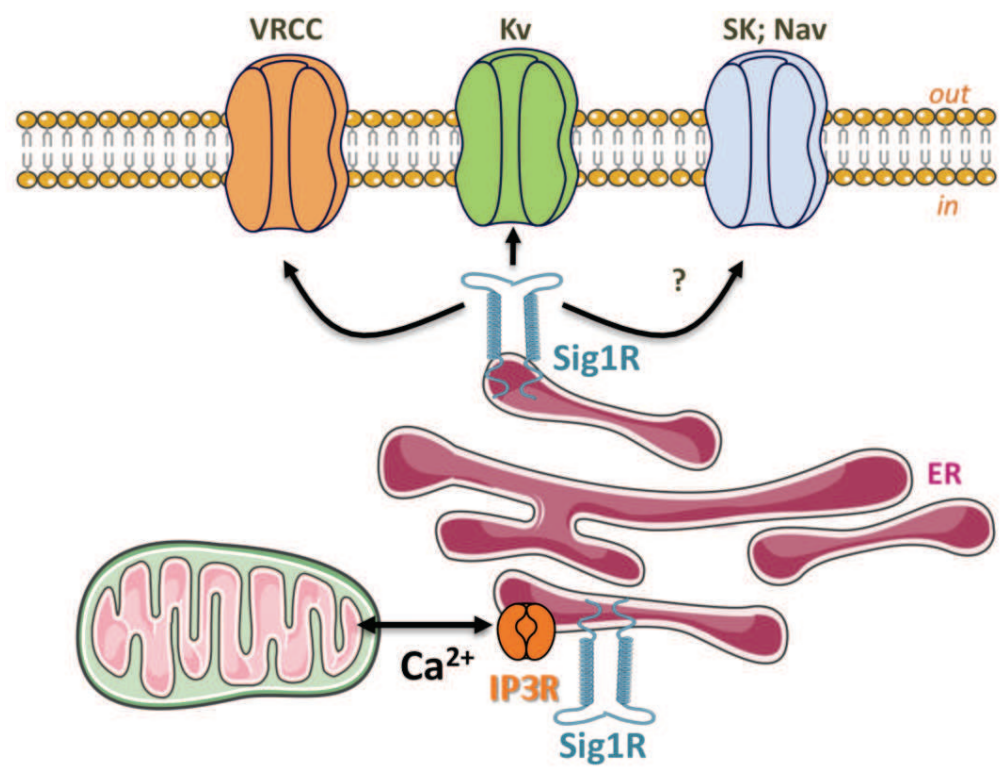

Fig. 3. Sig1R modulation on ion channels: A putative model. Under ER stress, Sig1R stabilizes IP3 receptors and regulates $\mathrm{Ca}^{2+}$ influx from ER to mitochondria to protect cells from apoptosis (Hayashi \& Su, 2007). Sig1R also modulates VRCC and Kv channels to reduce AVD, enhancing apoptosis resistance (Renaudo et al., 2004; Renaudo et al., 2007). Sig1R might target other channels such as Nav or SKCa 
Altogether, these data suggest that Sig1R might be a potential therapeutic target in melanoma. While the function and mechanisms of action of Sig1R in melanoma remain to be determined, it can be speculated that the protein regulates various ion channels of interest involved in proliferation and/or invasiveness. Sigma ligands might then be used to inhibit these channels specifically in melanoma.

\section{Channel proteins and anti-cancer therapy for melanoma}

In summary, there are at least 8 channels or groups of channels that have been suggested as anticancer or antimetastatic therapeutic targets: Store-Operated Channels (SOCs) (including Stim 1 and Orai1); P2X7R; TRPM8; sodium pump $\left(\mathrm{Na}^{+}, \mathrm{K}^{+}\right.$-ATPase); SK3/KCa2.3 channel; the VGKC Eag1; Nav1.6 and Sig1R. In absence of the identification of cancer-associated mutant ion channel molecules, there is no ideal and specific target in the field of ion channels, like the other potential therapeutic targets corresponding to wild-type molecules. The Sig1R does not follow this rule because it is suspected of having cancer-specific interactions with ion channels. Identification of such specific cancer associated interactions of Sig1R with channel partners would be very attractive to target tumour cells because they offer the possibility of minimizing toxic effects to non-tumour cells. As tumour eradication is obviously preferable to tumour arrest, targeting ion channels involved only in cell proliferation, which would help rather to limit tumour expansion than to eliminate it, is conceivable in combination to other therapies. However, the inhibition of melanoma SOC channels would be helpful to overcome resistance to chemotherapy-induced apoptosis, and inversely the activation of P2X7R and TRPM8 or inhibition of sodium pump might lead to cell death. Finally, since metastatic melanoma is almost incurable because of lack of effective anti-metastatic therapies, the most promising ion channel candidates for melanoma are those that would target cellular processes involved in metastasis occurrence. Fortunately at least two ion channel candidates belong to this category; SK3/KCa2.3 and Nav1.6 channels.

Due to their cellular localisation, modulation of ion channels is easy and has many advantages that make it an ideal anti-cancerous therapeutic approach (e.g. extracellular targeting, excepted for stim1; restricted metabolic effects). The recent robotisation of patch clamp method, the electrophysiological method that measured ion channel activity, greatly facilitates the screening of new anti-channel drugs. The exploitation of anti-channel drug as anticancer drugs is currently still underdeveloped, may be due to their unintentional side effects on non-tumour tissues. This is specifically true for channels expressed in cardiomyocyte that might cause undesirable cardiac side effects (e.g. hERG). Arcangeli and coll have written an excellent review that addresses the altered expression of ion channels in cancer, their pharmacological blockers potentially usable in therapy and the numerous side effects predicted or known related to their inhibition (Arcangeli et al., 2009). Thus, before developing new therapeutic approaches through new biological targets, some prerequisites must be considered to predict or avoid some side effects (expression level and biological function between tumour and non-tumour tissue). With regard to melanoma, our current knowledge are relatively fragmented and remained to be deepening, but for some channels such as SK3, TRPM8, sodium pump, Nav1.6, Sig1R, recent data are sufficient to consider them as good druggable targets. Note that for two of them, TRPM8 and sodium pump, their expression in human clinical samples has already been demonstrated. If multiple cellular targets of melanoma have been identified, pharmacological drugs remain to be developed. Note that most ion channels belong to large families of channels and that it is relatively difficult to develop specific agonists or antagonists for one particular channel. In oncology 
the concept to use ion channel modulators in therapy is recent but might be compensated by the active development of these modulating agents in other medical disciplines (e. $\mathrm{g}$. neurology, cardiology).

Actually, there is an increasing list of recent patents related to the use of ion channels modulators in anticancer therapy (Le Guennec et al., 2007; Villalonga et al., 2007). To date, only KCa3.1/SK4 blockers have been proposed for the treatment of prostate, pancreatic, and endometrial cancer, based on their ability to inhibit in vitro cell proliferation. So far only few blockers, particularly the clotrimazole analogue to TRAM-34 (Patent WO/2007/033307, 22.03.2007), emerge as promising anticancer drugs, presumably as adjuvant of cancer therapy. In this regard, SK3 channel has been proposed as a tool for the in vitro screening of compounds that might inhibit SK3-dependent cell migration and metastasis development (WO/2008/015267). In regards to Sig1R, the number of patents in the field of cancer is rather low, and concerns mainly imagery (PET scan) for the early detection of tumours. We believe that the identification of cancer-associated interaction between Sig1R and a specific ion channels might propose the more specific of anti-cancer therapies. Indeed if Sig1R represent a promising target for cancer therapy, physical and functional links with ion channels expressed in melanoma require to be explored, especially for the putative coupling with Nav1.6, Kv1.3, Eag1 and SK3 channels, channels that have been already link to some behaviour of melanoma cells (see above). To our knowledge, no patented molecules or drugs has been established for its ability to recognize a cancer-associated complex of Sig1R/ ion channel.

\section{Conclusion - perspectives}

In conclusion, there is now strong evidence that numerous ion channels play important roles in carcinogenesis in participating actively to determine the common features of cancer cells, such as unlimited proliferative potential, evasion of cell death, angiogenesis, reduction of adhesion, invasion and metastasis development. In melanogenesis, additional research remains to be done such, as clinical relevance related to channel type expression, prognostic information, discovery of melanoma-specific complexes, development of more potent and specific inhibitors. To expect reaching the ideal specificity of a new drug toward melanoma, effort might be done in the identification of cancer-associated mutants of ion channel molecules, in the identification of specific complexes of channels / partners or channels / subunits associated to melanoma. Nevertheless, the important work of the cell physiologists, oncologists, chemists, biologists and pharmacologists has shown the promising interest of ion channel as therapeutic targets.

\section{Acknowledgment}

Research in our groups is supported by institutional grants from INSERM and CNRS, by INCa, Canceropole Grand Ouest, Région Centre, Ligue Contre le Cancer, Ti'Toine Normandie, by Agence Nationale pour la Recherche. A.C. is the recipient of a fellowship from INCa.

\section{References}

Adinolfi, E., Melchiorri, L., Falzoni, S., Chiozzi, P., Morelli, A., Tieghi, A., Cuneo, A., Castoldi, G., Di Virgilio, F., and Baricordi, O.R. (2002). P2X7 receptor expression in evolutive and indolent forms of chronic B lymphocytic leukemia. Blood 99, 706-708. 
Afrasiabi, E., Hietamaki, M., Viitanen, T., Sukumaran, P., Bergelin, N., and Tornquist, K. (2010). Expression and significance of HERG (KCNH2) potassium channels in the regulation of MDA-MB-435S melanoma cell proliferation and migration. Cell Signal 22, 57-64.

Allen, D.H., Lepple-Wienhues, A., and Cahalan, M.D. (1997). Ion channel phenotype of melanoma cell lines. J Membr Biol 155, 27-34.

Altomare, D.A., and Testa, J.R. (2005). Perturbations of the AKT signaling pathway in human cancer. Oncogene 24, 7455-7464.

Arcangeli, A., Crociani, O., Lastraioli, E., Masi, A., Pillozzi, S., and Becchetti, A. (2009). Targeting ion channels in cancer: a novel frontier in antineoplastic therapy. Curr Med Chem 16, 66-93.

Artym, V.V., and Petty, H.R. (2002). Molecular proximity of Kv1.3 voltage-gated potassium channels and beta(1)-integrins on the plasma membrane of melanoma cells: effects of cell adherence and channel blockers. J Gen Physiol 120, 29-37.

Asher, V., Sowter, H., Shaw, R., Bali, A., and Khan, R. (2010). Eag and HERG potassium channels as novel therapeutic targets in cancer. World J Surg Oncol 8, 113.

Assa-Kunik, E., Fishman, D., Kellman-Pressman, S., Tsory, S., Elhyany, S., Baharir, O., and Segal, S. (2003). Alterations in the expression of MHC class I glycoproteins by B16BL6 melanoma cells modulate insulin receptor-regulated signal transduction and augment [correction of augments] resistance to apoptosis. J Immunol 171, 29452952.

Aydar, E., Onganer, P., Perrett, R., Djamgoz, M.B., and Palmer, C.P. (2006). The expression and functional characterization of sigma (sigma) 1 receptors in breast cancer cell lines. Cancer Lett 242, 245-257.

Aydar, E., Palmer, C.P., and Djamgoz, M.B. (2004). Sigma receptors and cancer: possible involvement of ion channels. Cancer Res 64, 5029-5035.

Becker, J.C., Kirkwood, J.M., Agarwala, S.S., Dummer, R., Schrama, D., and Hauschild, A. (2006). Molecularly targeted therapy for melanoma: current reality and future options. Cancer 107, 2317-2327.

Bellacosa, A., Testa, J.R., Moore, R., and Larue, L. (2004). A portrait of AKT kinases: human cancer and animal models depict a family with strong individualities. Cancer Biol Ther 3, 268-275.

Bian, G.H., Cao, G., Lv, X.Y., Li, Q.W., Sun, H., Xiao, Y., Ai, J.Z., Yang, Q.T., Duan, J.J., Wang, Y.D., et al. (2010). Down-regulation of Pkd2 by siRNAs suppresses cell-cell adhesion in the mouse melanoma cells. Mol Biol Rep 37, 2387-2395.

Bianchi, L., Wible, B., Arcangeli, A., Taglialatela, M., Morra, F., Castaldo, P., Crociani, O., Rosati, B., Faravelli, L., Olivotto, M., et al. (1998). herg encodes a $\mathrm{K}^{+}$current highly conserved in tumours of different histogenesis: a selective advantage for cancer cells? Cancer Res 58, 815-822.

Bielanska, J., Hernandez-Losa, J., Perez-Verdaguer, M., Moline, T., Somoza, R., Ramon, Y.C.S., Condom, E., Ferreres, J.C., and Felipe, A. (2009). Voltage-dependent potassium channels Kv1.3 and Kv1.5 in human cancer. Curr Cancer Drug Targets 9, 904-914.

Bijlenga, P., Occhiodoro, T., Liu, J.H., Bader, C.R., Bernheim, L., and Fischer-Lougheed, J. (1998). An ether -a-go-go $\mathrm{K}^{+}$current, Ih-eag, contributes to the hyperpolarization of human fusion-competent myoblasts. J Physiol 512 ( Pt 2), 317-323. 
Bodding, M., Wissenbach, U., and Flockerzi, V. (2007). Characterisation of TRPM8 as a pharmacophore receptor. Cell Calcium 42, 618-628.

Bond, C.T., Maylie, J., and Adelman, J.P. (2005). SK channels in excitability, pacemaking and synaptic integration. Curr Opin Neurobiol 15, 305-311.

Boukerche, H., Su, Z.Z., Kang, D.C., and Fisher, P.B. (2004). Identification and cloning of genes displaying elevated expression as a consequence of metastatic progression in human melanoma cells by rapid subtraction hybridization. Gene 343, 191-201.

Brevet, M., Haren, N., Sevestre, H., Merviel, P., and Ouadid-Ahidouch, H. (2009). DNA methylation of $\mathrm{K}(\mathrm{v}) 1.3$ potassium channel gene promoter is associated with poorly differentiated breast adenocarcinoma. Cell Physiol Biochem 24, 25-32.

Bringmann, A., Pannicke, T., Moll, V., Milenkovic, I., Faude, F., Enzmann, V., Wolf, S., and Reichenbach, A. (2001). Upregulation of P2X(7) receptor currents in Muller glial cells during proliferative vitreoretinopathy. Invest Ophthalmol Vis Sci 42, 860-867.

Brisson, L., Gillet, L., Calaghan, S., Besson, P., Le Guennec, J.Y., Roger, S., and Gore, J. (2011). $\mathrm{Na}(\mathrm{V}) 1.5$ enhances breast cancer cell invasiveness by increasing NHE1-dependent $\mathrm{H}\left({ }^{+}\right)$efflux in caveolae. Oncogene. 30, 2070-2076

Burnstock, G. (1972). Purinergic nerves. Pharmacol Rev 24, 509-581.

Burnstock, G. (2006). Purinergic signalling. Br J Pharmacol 147 Suppl 1, S172-181.

Carrithers, M.D., Chatterjee, G., Carrithers, L.M., Offoha, R., Iheagwara, U., Rahner, C., Graham, M., and Waxman, S.G. (2009). Regulation of podosome formation in macrophages by a splice variant of the sodium channel SCN8A. J Biol Chem 284, 8114-8126.

Chambers, A.F. (2009). MDA-MB-435 and M14 Cell Lines: Identical but not M14 Melanoma? Cancer Res $695292-5293$

Chandy, K.G., Wulff, H., Beeton, C., Pennington, M., Gutman, G.A., and Cahalan, M.D. $(2004) . \mathrm{K}^{+}$channels as targets for specific immunomodulation. Trends Pharmacol Sci 25, 280-289.

Chantôme, A., Girault, A., Potier, M., Collin, C., Vaudin, P., Pages, J.C., Vandier, C., and Joulin, V. (2009). KCa2.3 channel-dependent hyperpolarization increases melanoma cell motility. Exp Cell Res 315, 3620-3630.

Chen, M.X., Gorman, S.A., Benson, B., Singh, K., Hieble, J.P., Michel, M.C., Tate, S.N., and Trezise, D.J. (2004). Small and intermediate conductance $\mathrm{Ca}\left({ }^{2+}\right)$-activated $\mathrm{K}^{+}$ channels confer distinctive patterns of distribution in human tissues and differential cellular localisation in the colon and corpus cavernosum. Naunyn Schmiedebergs Arch Pharmacol 369, 602-615.

Chen, Y., Bathula, S.R., Yang, Q., and Huang, L. (2010). Targeted nanoparticles deliver siRNA to melanoma. J Invest Dermatol 130, 2790-2798.

Cherubini, A., Hofmann, G., Pillozzi, S., Guasti, L., Crociani, O., Cilia, E., Di Stefano, P., Degani, S., Balzi, M., Olivotto, M., et al. (2005). Human ether-a-go-go-related gene 1 channels are physically linked to beta1 integrins and modulate adhesion-dependent signaling. Mol Biol Cell 16, 2972-2983.

Collier, T.L., Waterhouse, R.N., and Kassiou, M. (2007). Imaging sigma receptors: applications in drug development. Curr Pharm Des 13, 51-72.

Crociani, O., Guasti, L., Balzi, M., Becchetti, A., Wanke, E., Olivotto, M., Wymore, R.S., and Arcangeli, A. (2003). Cell cycle-dependent expression of HERG1 and HERG1B isoforms in tumour cells. J Biol Chem 278, 2947-2955. 
Cruse, G., Duffy, S.M., Brightling, C.E., and Bradding, P. (2006). Functional KCa3.1 K+ channels are required for human lung mast cell migration. Thorax 61, 880-885.

Dai, D.L., Martinka, M., and Li, G. (2005). Prognostic significance of activated Akt expression in melanoma: a clinicopathologic study of 292 cases. J Clin Oncol 23, 1473-1482.

Deb, T.B., Coticchia, C.M., and Dickson, R.B. (2004). Calmodulin-mediated activation of Akt regulates survival of c-Myc-overexpressing mouse mammary carcinoma cells. J Biol Chem 279, 38903-38911.

DeCoursey, T.E., Chandy, K.G., Gupta, S., and Cahalan, M.D. (1984). Voltage-gated K+ channels in human T lymphocytes: a role in mitogenesis? Nature 307, 465-468.

Deli, T., Varga, N., Adam, A., Kenessey, I., Raso, E., Puskas, L.G., Tovari, J., Fodor, J., Feher, M., Szigeti, G.P., et al. (2007). Functional genomics of calcium channels in human melanoma cells. Int J Cancer 121, 55-65.

Demaurex, N., Poburko, D., and Frieden, M. (2009). Regulation of plasma membrane calcium fluxes by mitochondria. Biochim Biophys Acta 1787, 1383-1394.

Di Virgilio, F. (2007). Liaisons dangereuses: P2X(7) and the inflammasome. Trends Pharmacol Sci 28, 465-472.

Di Virgilio, F., Chiozzi, P., Falzoni, S., Ferrari, D., Sanz, J.M., Venketaraman, V., and Baricordi, O.R. (1998). Cytolytic P2X purinoceptors. Cell Death Differ 5, 191-199.

Diaz, D., Delgadillo, D.M., Hernandez-Gallegos, E., Ramirez-Dominguez, M.E., Hinojosa, L.M., Ortiz, C.S., Berumen, J., Camacho, J., and Gomora, J.C. (2007). Functional expression of voltage-gated sodium channels in primary cultures of human cervical cancer. J Cell Physiol 210, 469-478.

Diaz, L., Ceja-Ochoa, I., Restrepo-Angulo, I., Larrea, F., Avila-Chavez, E., Garcia-Becerra, R., Borja-Cacho, E., Barrera, D., Ahumada, E., Gariglio, P., et al. (2009). Estrogens and human papilloma virus oncogenes regulate human ether-a-go-go-1 potassium channel expression. Cancer Res 69, 3300-3307.

Diss, J.K., Archer, S.N., Hirano, J., Fraser, S.P., and Djamgoz, M.B. (2001). Expression profiles of voltage-gated $\mathrm{Na}\left({ }^{+}\right)$channel alpha-subunit genes in rat and human prostate cancer cell lines. Prostate 48, 165-178.

Dong, B., Valencia, C.A., and Liu, R. (2007). Ca( $\left({ }^{2+}\right) /$ calmodulin directly interacts with the pleckstrin homology domain of AKT1. J Biol Chem 282, 25131-25140.

Downie, B.R., Sanchez, A., Knotgen, H., Contreras-Jurado, C., Gymnopoulos, M., Weber, C., Stuhmer, W., and Pardo, L.A. (2008). Eag1 expression interferes with hypoxia homeostasis and induces angiogenesis in tumours. J Biol Chem 283, 36234-36240.

Duncan, L.M., Deeds, J., Hunter, J., Shao, J., Holmgren, L.M., Woolf, E.A., Tepper, R.I., and Shyjan, A.W. (1998). Down-regulation of the novel gene melastatin correlates with potential for melanoma metastasis. Cancer Res 58, 1515-1520.

Fedida-Metula, S., Elhyany, S., Tsory, S., Segal, S., Hershfinkel, M., Sekler, I., and Fishman, D. (2008). Targeting lipid rafts inhibits protein kinase B by disrupting calcium homeostasis and attenuates malignant properties of melanoma cells. Carcinogenesis 29, 1546-1554.

Feldman, B., Fedida-Metula, S., Nita, J., Sekler, I., and Fishman, D. (2010). Coupling of mitochondria to store-operated $\mathrm{Ca}\left({ }^{2+}\right)$-signaling sustains constitutive activation of protein kinase B/Akt and augments survival of malignant melanoma cells. Cell Calcium 47, 525-537. 
Feng, Y.H., Li, X., Wang, L., Zhou, L., and Gorodeski, G.I. (2006a). A truncated P2X7 receptor variant (P2X7-j) endogenously expressed in cervical cancer cells antagonizes the full-length P2X7 receptor through hetero-oligomerization. J Biol Chem 281, 17228-17237.

Feng, Y.H., Li, X., Zeng, R., and Gorodeski, G.I. (2006b). Endogenously expressed truncated P2X7 receptor lacking the c-terminus is preferentially upregulated in epithelial cancer cells and fails to mediate ligand-induced pore formation and apoptosis. Nucleosides Nucleotides Nucleic Acids 25, 1271-1276.

Fountain, S.J., Cao, L., Young, M.T., and North, R.A. (2008). Permeation properties of a P2X receptor in the green algae Ostreococcus tauri. J Biol Chem 283, 15122-15126.

Fountain, S.J., Parkinson, K., Young, M.T., Cao, L., Thompson, C.R., and North, R.A. (2007). An intracellular P2X receptor required for osmoregulation in Dictyostelium discoideum. Nature 448, 200-203.

Fraser, S.P., Diss, J.K., Chioni, A.M., Mycielska, M.E., Pan, H., Yamaci, R.F., Pani, F., Siwy, Z., Krasowska, M., Grzywna, Z., et al. (2005). Voltage-gated sodium channel expression and potentiation of human breast cancer metastasis. Clin Cancer Res 11, 5381-5389.

Friebe, M., Mahmood, A., Bolzati, C., Drews, A., Johannsen, B., Eisenhut, M., Kraemer, D., Davison, A., and Jones, A.G. (2001). [99mTc]oxotechnetium(V) complexes amineamide-dithiol chelates with dialkylaminoalkyl substituents as potential diagnostic probes for malignant melanoma. J Med Chem 44, 3132-3140.

Gao, R., Shen, Y., Cai, J., Lei, M., and Wang, Z. (2010). Expression of voltage-gated sodium channel alpha subunit in human ovarian cancer. Oncol Rep 23, 1293-1299.

Gavrilova-Ruch, O., Schonherr, K., Gessner, G., Schonherr, R., Klapperstuck, T., Wohlrab, W., and Heinemann, S.H. (2002). Effects of imipramine on ion channels and proliferation of IGR1 melanoma cells. J Membr Biol 188, 137-149.

Gilabert, J.A., Bakowski, D., and Parekh, A.B. (2001). Energized mitochondria increase the dynamic range over which inositol 1,4,5-trisphosphate activates store-operated calcium influx. EMBO J 20, 2672-2679.

Gilabert, J.A., and Parekh, A.B. (2000). Respiring mitochondria determine the pattern of activation and inactivation of the store-operated $\mathrm{Ca}\left({ }^{2+}\right)$ current $\mathrm{I}(\mathrm{CRAC})$. EMBO J 19, 6401-6407.

Gillet, L., Roger, S., Besson, P., Lecaille, F., Gore, J., Bougnoux, P., Lalmanach, G., and Le Guennec, J.Y. (2009). Voltage-gated Sodium Channel Activity Promotes Cysteine Cathepsin-dependent Invasiveness and Colony Growth of Human Cancer Cells. J Biol Chem 284, 8680-8691.

Glitsch, M.D., Bakowski, D., and Parekh, A.B. (2002). Store-operated Ca ${ }^{2+}$ entry depends on mitochondrial $\mathrm{Ca}^{2+}$ uptake. EMBO J 21, 6744-6754.

Gomez-Varela, D., Zwick-Wallasch, E., Knotgen, H., Sanchez, A., Hettmann, T., Ossipov, D., Weseloh, R., Contreras-Jurado, C., Rothe, M., Stuhmer, W., et al. (2007). Monoclonal antibody blockade of the human Eag1 potassium channel function exerts antitumour activity. Cancer Res 67, 7343-7349.

Greig, A.V., Linge, C., Healy, V., Lim, P., Clayton, E., Rustin, M.H., McGrouther, D.A., and Burnstock, G. (2003). Expression of purinergic receptors in non-melanoma skin cancers and their functional roles in A431 cells. J Invest Dermatol 121, 315-327. 
Guasti, L., Crociani, O., Redaelli, E., Pillozzi, S., Polvani, S., Masselli, M., Mello, T., Galli, A., Amedei, A., Wymore, R.S., et al. (2008). Identification of a posttranslational mechanism for the regulation of hERG1 $\mathrm{K}^{+}$channel expression and hERG1 current density in tumour cells. Mol Cell Biol 28, 5043-5060.

Gutman, G.A., Chandy, K.G., Adelman, J.P., Aiyar, J., Bayliss, D.A., Clapham, D.E., Covarriubias, M., Desir, G.V., Furuichi, K., Ganetzky, B., et al. (2003). International Union of Pharmacology. XLI. Compendium of voltage-gated ion channels: potassium channels. Pharmacol Rev 55, 583-586.

Habela, C.W., Ernest, N.J., Swindall, A.F., and Sontheimer, H. (2009). Chloride accumulation drives volume dynamics underlying cell proliferation and migration. J Neurophysiol 101, 750-757.

Hanner, M., Moebius, F.F., Flandorfer, A., Knaus, H.G., Striessnig, J., Kempner, E., and Glossmann, H. (1996). Purification, molecular cloning, and expression of the mammalian sigma1-binding site. Proc Natl Acad Sci U S A 93, 8072-8077.

Hayashi, T., and Su, T.P. (2007). Sigma-1 receptor chaperones at the ER-mitochondrion interface regulate $\mathrm{Ca}\left({ }^{2+}\right)$ signaling and cell survival. Cell 131, 596-610.

Hegle, A.P., Marble, D.D., and Wilson, G.F. (2006). A voltage-driven switch for ionindependent signaling by ether-a-go-go K+ channels. Proc Natl Acad Sci U S A 103, 2886-2891.

Hemmerlein, B., Weseloh, R.M., Mello de Queiroz, F., Knotgen, H., Sanchez, A., Rubio, M.E., Martin, S., Schliephacke, T., Jenke, M., Heinz Joachim, R., et al. (2006). Overexpression of Eag1 potassium channels in clinical tumours. Mol Cancer 5, 41.

Herrera, G.M., Pozo, M.J., Zvara, P., Petkov, G.V., Bond, C.T., Adelman, J.P., and Nelson, M.T. (2003). Urinary bladder instability induced by selective suppression of the murine small conductance calcium-activated potassium (SK3) channel. J Physiol 551, 893-903.

Herrera, Y., Katnik, C., Rodriguez, J.D., Hall, A.A., Willing, A., Pennypacker, K.R., and Cuevas, J. (2008). sigma-1 receptor modulation of acid-sensing ion channel a (ASIC1a) and ASIC1a-induced $\mathrm{Ca}^{2+}$ influx in rat cortical neurons. J Pharmacol Exp Ther 327, 491-502.

House, C.D., Vaske, C.J., Schwartz, A.M., Obias, V., Frank, B., Luu, T., Sarvazyan, N., Irby, R., Strausberg, R.L., Hales, T.G., et al. (2010). Voltage-gated $\mathrm{Na}^{+}$channel SCN5A is a key regulator of a gene transcriptional network that controls colon cancer invasion. Cancer Res 70, 6957-6967.

$\mathrm{Hu}, \mathrm{J}$. , and Verkman, A.S. (2006). Increased migration and metastatic potential of tumour cells expressing aquaporin water channels. FASEB J 20, 1892-1894.

Ishii, T.M., Maylie, J., and Adelman, J.P. (1997). Determinants of apamin and d-tubocurarine block in SK potassium channels. J Biol Chem 272, 23195-23200.

Jager, H., Dreker, T., Buck, A., Giehl, K., Gress, T., and Grissmer, S. (2004). Blockage of intermediate-conductance $\mathrm{Ca}^{2+}$-activated $\mathrm{K}^{+}$channels inhibit human pancreatic cancer cell growth in vitro. Mol Pharmacol 65, 630-638.

Jelassi, B., Chantôme, A., Alcaraz-Perez, F., Baroja-Mazo, A., Cayuela, M.L., Pelegrin, P., Surprenant, A., and Roger, S. (2011). P2X(7) receptor activation enhances SK3 channels- and cystein cathepsin-dependent cancer cells invasiveness. Oncogene.

Johannessen, M., Ramachandran, S., Riemer, L., Ramos-Serrano, A., Ruoho, A.E., and Jackson, M.B. (2009). Voltage-gated sodium channel modulation by sigma-receptors 
in cardiac myocytes and heterologous systems. Am J Physiol Cell Physiol 296, C10491057.

Kim, S.Y., Sivaguru, M., and Stacey, G. (2006). Extracellular ATP in plants. Visualization, localization, and analysis of physiological significance in growth and signaling. Plant Physiol 142, 984-992.

Klein, W.M., Wu, B.P., Zhao, S., Wu, H., Klein-Szanto, A.J., and Tahan, S.R. (2007). Increased expression of stem cell markers in malignant melanoma. Mod Pathol 20, 102-107.

Lastraioli, E., Guasti, L., Crociani, O., Polvani, S., Hofmann, G., Witchel, H., Bencini, L., Calistri, M., Messerini, L., Scatizzi, M., et al. (2004). herg1 gene and HERG1 protein are overexpressed in colorectal cancers and regulate cell invasion of tumour cells. Cancer Res 64, 606-611.

Le Guennec, J.Y., Ouadid-Ahidouch, H., Soriani, O., Besson, P., Ahidouch, A., and Vandier, C. (2007). Voltage-gated ion channels, new targets in anti-cancer research. Recent Pat Anticancer Drug Discov 2, 189-202.

Lepple-Wienhues, A., Berweck, S., Bohmig, M., Leo, C.P., Meyling, B., Garbe, C., and Wiederholt, M. (1996). $\mathrm{K}^{+}$channels and the intracellular calcium signal in human melanoma cell proliferation. J Membr Biol 151, 149-157.

Lewis, R.S. (2001). Calcium signaling mechanisms in T lymphocytes. Annu Rev Immunol 19, 497-521.

Li, X., Zhou, L., Feng, Y.H., Abdul-Karim, F.W., and Gorodeski, G.I. (2006). The P2X7 receptor: a novel biomarker of uterine epithelial cancers. Cancer Epidemiol Biomarkers Prev 15, 1906-1913.

Louis, M., Zanou, N., Van Schoor, M., and Gailly, P. (2008). TRPC1 regulates skeletal myoblast migration and differentiation. J Cell Sci 121, 3951-3959.

Mackenzie, A.B., Young, M.T., Adinolfi, E., and Surprenant, A. (2005). Pseudoapoptosis induced by brief activation of ATP-gated P2X7 receptors. J Biol Chem 280, 3396833976.

Malli, R., Frieden, M., Osibow, K., Zoratti, C., Mayer, M., Demaurex, N., and Graier, W.F. (2003). Sustained $\mathrm{Ca}^{2+}$ transfer across mitochondria is Essential for mitochondrial $\mathrm{Ca}^{2+}$ buffering, sore-operated $\mathrm{Ca}^{2+}$ entry, and $\mathrm{Ca}^{2+}$ store refilling. J Biol Chem 278, 44769-44779.

Martin, S., Lino-de-Oliveira, C., Joca, S.R., Weffort de Oliveira, R., Echeverry, M.B., Da Silva, C.A., Pardo, L., Stuhmer, W., and Bel, E.D. (2010). Eag 1, Eag 2 and Kcnn3 gene brain expression of isolated reared rats. Genes Brain Behav 9, 918-924.

Martin, W.R., Eades, C.G., Thompson, J.A., Huppler, R.E., and Gilbert, P.E. (1976). The effects of morphine- and nalorphine- like drugs in the nondependent and morphine-dependent chronic spinal dog. J Pharmacol Exp Ther 197, 517-532.

Mathieu, V., Pirker, C., Martin de Lassalle, E., Vernier, M., Mijatovic, T., DeNeve, N., Gaussin, J.F., Dehoux, M., Lefranc, F., Berger, W., et al. (2009). The sodium pump alpha1 sub-unit: a disease progression-related target for metastatic melanoma treatment. J Cell Mol Med 13, 3960-3972.

Megalizzi, V., Mathieu, V., Mijatovic, T., Gailly, P., Debeir, O., De Neve, N., Van Damme, M., Bontempi, G., Haibe-Kains, B., Decaestecker, C., et al. (2007). 4-IBP, a sigma1 receptor agonist, decreases the migration of human cancer cells, including glioblastoma cells, in vitro and sensitizes them in vitro and in vivo to cytotoxic insults of proapoptotic and proautophagic drugs. Neoplasia 9, 358-369. 
Meyer, R., Schonherr, R., Gavrilova-Ruch, O., Wohlrab, W., and Heinemann, S.H. (1999). Identification of ether a go-go and calcium-activated potassium channels in human melanoma cells. J Membr Biol 171, 107-115.

Millership, J.E., Devor, D.C., Hamilton, K.L., Balut, C.M., Bruce, J.I., and Fearon, I.M. (2010). Calcium Activated $\mathrm{K}^{+}$Channels Increase Cell Proliferation Independent of $\mathrm{K}^{+}$ Conductance. Am J Physiol Cell Physiol in press.

Monaghan, A.S., Benton, D.C., Bahia, P.K., Hosseini, R., Shah, Y.A., Haylett, D.G., and Moss, G.W. (2004). The SK3 subunit of small conductance $\mathrm{Ca}^{2+}$-activated $\mathrm{K}^{+}$channels interacts with both SK1 and SK2 subunits in a heterologous expression system. J Biol Chem 279, 1003-1009.

Monk, M., and Holding, C. (2001). Human embryonic genes re-expressed in cancer cells. Oncogene 20, 8085-8091.

Monzani, E., Bazzotti, R., Perego, C., and La Porta, C.A. (2009). AQP1 is not only a water channel: it contributes to cell migration through Lin7/beta-catenin. PLoS One 4, e6167.

Morth, J.P., Pedersen, B.P., Buch-Pedersen, M.J., Andersen, J.P., Vilsen, B., Palmgren, M.G., and Nissen, P. (2011). A structural overview of the plasma membrane $\mathrm{Na}^{+}, \mathrm{K}^{+}-$ ATPase and $\mathrm{H}^{+}$-ATPase ion pumps. Nat Rev Mol Cell Biol 12, 60-70.

Nilius, B., Schwarz, G., and Droogmans, G. (1993). Control of intracellular calcium by membrane potential in human melanoma cells. Am J Physiol 265, C1501-1510.

Nilius, B., and Wohlrab, W. (1992). Potassium channels and regulation of proliferation of human melanoma cells. J Physiol 445, 537-548.

North, R.A. (2002). Molecular physiology of P2X receptors. Physiol Rev 82, 1013-1067.

Ohshima, Y., Tsukimoto, M., Takenouchi, T., Harada, H., Suzuki, A., Sato, M., Kitani, H., and Kojima, S. (2010). gamma-Irradiation induces P2X(7) receptor-dependent ATP release from B16 melanoma cells. Biochim Biophys Acta 1800, 40-46.

Onganer, P.U., and Djamgoz, M.B. (2005). Small-cell Lung Cancer (Human): Potentiation of Endocytic Membrane Activity by Voltage-gated $\mathrm{Na}\left({ }^{+}\right)$Channel Expression in Vitro. J Membr Biol 204, 67-75.

Orfanelli, U., Wenke, A.K., Doglioni, C., Russo, V., Bosserhoff, A.K., and Lavorgna, G. (2008). Identification of novel sense and antisense transcription at the TRPM2 locus in cancer. Cell Res 18, 1128-1140.

Ouadid-Ahidouch, H., Roudbaraki, M., Delcourt, P., Ahidouch, A., Joury, N., and Prevarskaya, N. (2004). Functional and molecular identification of intermediateconductance $\mathrm{Ca}\left({ }^{2+}\right)$-activated $\mathrm{K}\left({ }^{+}\right)$channels in breast cancer cells: association with cell cycle progression. Am J Physiol Cell Physiol 287, C125-134.

Pardo, L.A., del Camino, D., Sanchez, A., Alves, F., Bruggemann, A., Beckh, S., and Stuhmer, W. (1999). Oncogenic potential of EAG K(+) channels. Embo J 18, 5540-5547.

Pardo, L.A., and Suhmer, W. (2008). Eag1 as a cancer target. Expert Opin Ther Targets 12, 837843.

Parekh, A.B. (2003). Store-operated $\mathrm{Ca}^{2+}$ entry: dynamic interplay between endoplasmic reticulum, mitochondria and plasma membrane. J Physiol 547, 333-348.

Parekh, A.B. (2008). Mitochondrial regulation of store-operated CRAC channels. Cell Calcium $44,6-13$

Parekh, A.B., and Putney, J.W., Jr. (2005). Store-operated calcium channels. Physiol Rev 85, 757-810. 
Pelegrin, P. (2008). Targeting interleukin-1 signaling in chronic inflammation: focus on P2X(7) receptor and Pannexin-1. Drug News Perspect 21, 424-433.

Pelegrin, P., and Surprenant, A. (2006). Pannexin-1 mediates large pore formation and interleukin-1beta release by the ATP-gated P2X7 receptor. Embo J 25, 5071-5082.

Pillozzi, S., Brizzi, M.F., Balzi, M., Crociani, O., Cherubini, A., Guasti, L., Bartolozzi, B., Becchetti, A., Wanke, E., Bernabei, P.A., et al. (2002). HERG potassium channels are constitutively expressed in primary human acute myeloid leukemias and regulate cell proliferation of normal and leukemic hemopoietic progenitors. Leukemia 16, 1791-1798.

Pillozzi, S., Brizzi, M.F., Bernabei, P.A., Bartolozzi, B., Caporale, R., Basile, V., Boddi, V., Pegoraro, L., Becchetti, A., and Arcangeli, A. (2007). VEGFR-1 (FLT-1), beta1 integrin, and hERG $\mathrm{K}^{+}$channel for a macromolecular signaling complex in acute myeloid leukemia: role in cell migration and clinical outcome. Blood 110, 1238-1250.

Pillozzi, S., Masselli, M., De Lorenzo, E., Accordi, B., Cilia, E., Crociani, O., Amedei, A., Veltroni, M., D'Amico, M., Basso, G., et al. (2011). Chemotherapy resistance in acute lymphoblastic leukemia requires hERG1 channels and is overcome by hERG1 blockers. Blood 117, 902-914.

Pocsai, K., Kosztka, L., Bakondi, G., Gonczi, M., Fodor, J., Dienes, B., Szentesi, P., Kovacs, I., Feniger-Barish, R., Kopf, E., et al. (2006). Melanoma cells exhibit strong intracellular TASK-3-specific immunopositivity in both tissue sections and cell culture. Cell Mol Life Sci 63, 2364-2376.

Pongs, O., and Schwarz, J.R. (2010). Ancillary subunits associated with voltage-dependent $\mathrm{K}^{+}$channels. Physiol Rev 90, 755-796.

Potier, M., Joulin, V., Roger, S., Besson, P., Jourdan, M.L., Leguennec, J.Y., Bougnoux, P., and Vandier, C. (2006). Identification of SK3 channel as a new mediator of breast cancer cell migration. Mol Cancer Ther 5, 2946-2953.

Potier, M., Joulin, V., and Vandier, C. (2008). A method for the in vitro screening of anticancer compounds that inhibits SK3 activity, and said anti-cancer compounds. WO2008015267.

Potier, M., Tran, T.A., Chantôme, A., Girault, A., Joulin, V., Bougnoux, P., Vandier, C., and Pierre, F. (2010). Altered SK3/KCa2.3-mediated migration in adenomatous polyposis coli (Apc) mutated mouse colon epithelial cells. Biochem Biophys Res Commun 397, 42-47.

Prevarskaya, N., Zhang, L., and Barritt, G. (2007). TRP channels in cancer. Biochim Biophys Acta 1772, 937-946.

Putney, J.W., Jr. (1986). A model for receptor-regulated calcium entry. Cell Calcium 7, 1-12.

Quintana, A., Schwarz, E.C., Schwindling, C., Lipp, P., Kaestner, L., and Hoth, M. (2006). Sustained activity of calcium release-activated calcium channels requires translocation of mitochondria to the plasma membrane. J Biol Chem 281, 4030240309.

Rae, J.M., Creighton, C.J., Meck, J.M., Haddad, B.R., and Johnson, M.D. (2007). MDA-MB435 cells are derived from M14 melanoma cells--a loss for breast cancer, but a boon for melanoma research. Breast Cancer Res Treat 104, 13-19.

Raffaghello, L., Chiozzi, P., Falzoni, S., Di Virgilio, F., and Pistoia, V. (2006). The P2X7 receptor sustains the growth of human neuroblastoma cells through a substance Pdependent mechanism. Cancer Res 66, 907-914. 
Rao, J.N., Platoshyn, O., Golovina, V.A., Liu, L., Zou, T., Marasa, B.S., Turner, D.J., Yuan, J.X., and Wang, J.Y. (2006). TRPC1 functions as a store-operated $\mathrm{Ca}^{2+}$ channel in intestinal epithelial cells and regulates early mucosal restitution after wounding. Am J Physiol Gastrointest Liver Physiol 290, G782-792.

Rao, J.N., Platoshyn, O., Li, L., Guo, X., Golovina, V.A., Yuan, J.X., and Wang, J.Y. (2002). Activation of $\mathrm{K}(+)$ channels and increased migration of differentiated intestinal epithelial cells after wounding. Am J Physiol Cell Physiol 282, C885-898.

Rapaport, E. (1983). Treatment of human tumour cells with ADP or ATP yields arrest of growth in the S phase of the cell cycle. J Cell Physiol 114, 279-283.

Rapaport, E. (1988). Experimental cancer therapy in mice by adenine nucleotides. Eur J Cancer Clin Oncol 24, 1491-1497.

Rapaport, E., Fishman, R.F., and Gercel, C. (1983). Growth inhibition of human tumour cells in soft-agar cultures by treatment with low levels of adenosine 5'-triphosphate. Cancer Res 43, 4402-4406.

Rasheed, S., Mao, Z., Chan, J.M., and Chan, L.S. (2005). Is Melanoma a stem cell tumour? Identification of neurogenic proteins in trans-differentiated cells. J Transl Med 3, 14.

Rassendren, F., Buell, G.N., Virginio, C., Collo, G., North, R.A., and Surprenant, A. (1997). The permeabilizing ATP receptor, P2X7. Cloning and expression of a human cDNA. J Biol Chem 272, 5482-5486.

Renaudo, A., L'Hoste, S., Guizouarn, H., Borgese, F., and Soriani, O. (2007). Cancer cell cycle modulated by a functional coupling between sigma-1 receptors and Cl- channels. J Biol Chem 282, 2259-2267.

Renaudo, A., Watry, V., Chassot, A.A., Ponzio, G., Ehrenfeld, J., and Soriani, O. (2004). Inhibition of tumour cell proliferation by sigma ligands is associated with $\mathrm{K}^{+}$ Channel inhibition and p27kip1 accumulation. J Pharmacol Exp Ther 311, 1105-1114.

Rizzuto, R., and Pozzan, T. (2006). Microdomains of intracellular Ca2+: molecular determinants and functional consequences. Physiol Rev 86, 369-408.

Roger, S., Besson, P., and Le Guennec, J.Y. (2003). Involvement of a novel fast inward sodium current in the invasion capacity of a breast cancer cell line. Biochim Biophys Acta 1616, 107-111.

Roger, S., Gillet, L., Baroja-Mazo, A., Surprenant, A., and Pelegrin, P. (2010). C-terminal calmodulin-binding motif differentially controls human and rat P2X7 receptor current facilitation. J Biol Chem 285, 17514-17524.

Roger, S., Pelegrin, P., and Surprenant, A. (2008). Facilitation of P2X7 receptor currents and membrane blebbing via constitutive and dynamic calmodulin binding. J Neurosci 28, 6393-6401.

Roger, S., Rollin, J., Barascu, A., Besson, P., Raynal, P.I., Iochmann, S., Lei, M., Bougnoux, P., Gruel, Y., and Le Guennec, J.Y. (2007). Voltage-gated sodium channels potentiate the invasive capacities of human non-small-cell lung cancer cell lines. Int J Biochem Cell Biol 39, 774-786.

Romagnoli, R., Baraldi, P.G., Cruz-Lopez, O., Lopez-Cara, C., Preti, D., Borea, P.A., and Gessi, S. (2008). The P2X7 receptor as a therapeutic target. Expert Opin Ther Targets 12, 647-661.

Rouzaire-Dubois, B., Milandri, J.B., Bostel, S., and Dubois, J.M. (2000). Control of cell proliferation by cell volume alterations in rat C6 glioma cells. Pflugers Arch 440, 881888 . 
Rusznak, Z., Bakondi, G., Kosztka, L., Pocsai, K., Dienes, B., Fodor, J., Telek, A., Gonczi, M., Szucs, G., and Csernoch, L. (2008). Mitochondrial expression of the two-pore domain TASK-3 channels in malignantly transformed and non-malignant human cells. Virchows Arch 452, 415-426.

Saadoun, S., Papadopoulos, M.C., Hara-Chikuma, M., and Verkman, A.S. (2005). Impairment of angiogenesis and cell migration by targeted aquaporin-1 gene disruption. Nature 434, 786-792.

Sandoval, A.J., Riquelme, J.P., Carretta, M.D., Hancke, J.L., Hidalgo, M.A., and Burgos, R.A. (2007). Store-operated calcium entry mediates intracellular alkalinization, ERK1/2, and Akt/PKB phosphorylation in bovine neutrophils. J Leukoc Biol 82, 1266-1277.

Sanguinetti, M.C., Jiang, C., Curran, M.E., and Keating, M.T. (1995). A mechanistic link between an inherited and an acquired cardiac arrhythmia: HERG encodes the IKr potassium channel. Cell 81, 299-307.

Santella, L., Ercolano, E., and Nusco, G. (2005). The cell cycle: a new entry in the field of Ca\&lt;sup\&gt; ${ }^{2+} \& l t ; /$ sup\&gt; signaling. In Cellular and Molecular Life Sciences (BirkhÃ€user Basel), pp. 2405-2413.

Schmidt, J., Friebel, K., Schonherr, R., Coppolino, M.G., and Bosserhoff, A.K. (2010). Migration-associated secretion of melanoma inhibitory activity at the cell rear is supported by KCa3.1 potassium channels. Cell Res 20, 1224-1238.

Schwab, A. (2001). Function and spatial distribution of ion channels and transporters in cell migration. Am J Physiol Renal Physiol 280, F739-747.

Schwab, A., Reinhardt, J., Schneider, S.W., Gassner, B., and Schuricht, B. (1999). K(+) channel-dependent migration of fibroblasts and human melanoma cells. Cell Physiol Biochem 9, 126-132.

Schwarz, J.R., and Bauer, C.K. (2004). Functions of erg $\mathrm{K}^{+}$channels in excitable cells. J Cell Mol Med 8, 22-30.

Sellappan, S., Grijalva, R., Zhou, X., Yang, W., Eli, M.B., Mills, G.B., and Yu, D. (2004). Lineage infidelity of MDA-MB-435 cells: expression of melanocyte proteins in a breast cancer cell line. Cancer Res 64, 3479-3485.

Slater, M., Danieletto, S., and Barden, J.A. (2005). Expression of the apoptotic calcium channel P2X7 in the glandular epithelium. J Mol Histol 36, 159-165.

Slater, M., Danieletto, S., Gidley-Baird, A., Teh, L.C., and Barden, J.A. (2004a). Early prostate cancer detected using expression of non-functional cytolytic P2X7 receptors. Histopathology 44, 206-215.

Slater, M., Danieletto, S., Pooley, M., Cheng Teh, L., Gidley-Baird, A., and Barden, J.A. (2004b). Differentiation between cancerous and normal hyperplastic lobules in breast lesions. Breast Cancer Res Treat 83, 1-10.

Slater, M., Scolyer, R.A., Gidley-Baird, A., Thompson, J.F., and Barden, J.A. (2003). Increased expression of apoptotic markers in melanoma. Melanoma Res 13, 137-145.

Slipicevic, A., Holm, R., Nguyen, M.T., Bohler, P.J., Davidson, B., and Florenes, V.A. (2005). Expression of activated Akt and PTEN in malignant melanomas: relationship with clinical outcome. Am J Clin Pathol 124, 528-536.

Soengas, M.S., and Lowe, S.W. (2003). Apoptosis and melanoma chemoresistance. Oncogene 22, 3138-3151.

Solini, A., Cuccato, S., Ferrari, D., Santini, E., Gulinelli, S., Callegari, M.G., Dardano, A., Faviana, P., Madec, S., Di Virgilio, F., et al. (2008). Increased P2X7 receptor 
expression and function in thyroid papillary cancer: a new potential marker of the disease? Endocrinology 149, 389-396.

Soriani, O., Foll, F.L., Roman, F., Monnet, F.P., Vaudry, H., and Cazin, L. (1999a). A-Current down-modulated by sigma receptor in frog pituitary melanotrope cells through a $\mathrm{G}$ protein-dependent pathway. J Pharmacol Exp Ther 289, 321-328.

Soriani, O., Le Foll, F., Galas, L., Roman, F., Vaudry, H., and Cazin, L. (1999b). The sigmaligand (+)-pentazocine depresses $M$ current and enhances calcium conductances in frog melanotrophs. Am J Physiol 277, E73-80.

Soriani, O., Vaudry, H., Mei, Y.A., Roman, F., and Cazin, L. (1998). Sigma ligands stimulate the electrical activity of frog pituitary melanotrope cells through a G-proteindependent inhibition of potassium conductances. J Pharmacol Exp Ther 286, 163-171.

Stein, R.J., Santos, S., Nagatomi, J., Hayashi, Y., Minnery, B.S., Xavier, M., Patel, A.S., Nelson, J.B., Futrell, W.J., Yoshimura, N., et al. (2004). Cool (TRPM8) and hot (TRPV1) receptors in the bladder and male genital tract. J Urol 172, 1175-1178.

Stock, C., Mueller, M., Kraehling, H., Mally, S., Noel, J., Eder, C., and Schwab, A. (2007). pH nanoenvironment at the surface of single melanoma cells. Cell Physiol Biochem 20, 679-686.

Stock, C., and Schwab, A. (2009). Protons make tumour cells move like clockwork. Pflugers Arch 458, 981-992.

Su, T.P., Hayashi, T., Maurice, T., Buch, S., and Ruoho, A.E. (2010). The sigma-1 receptor chaperone as an inter-organelle signaling modulator. Trends Pharmacol Sci 31, 557566.

Surprenant, A., Rassendren, F., Kawashima, E., North, R.A., and Buell, G. (1996). The cytolytic P2Z receptor for extracellular ATP identified as a P2X receptor (P2X7). Science 272, 735-738.

Tajima, N., Schonherr, K., Niedling, S., Kaatz, M., Kanno, H., Schonherr, R., and Heinemann, S.H. (2006). $\mathrm{Ca}^{2+}$-activated $\mathrm{K}^{+}$channels in human melanoma cells are up-regulated by hypoxia involving hypoxia-inducible factor-1alpha and the von Hippel-Lindau protein. J Physiol 571, 349-359.

Taylor, M.S., Bonev, A.D., Gross, T.P., Eckman, D.M., Brayden, J.E., Bond, C.T., Adelman, J.P., and Nelson, M.T. (2003). Altered expression of small-conductance $\mathrm{Ca}^{2+}$ activated $\mathrm{K}^{+}(\mathrm{SK} 3)$ channels modulates arterial tone and blood pressure. Circ Res 93, 124-131.

Testa, J.R., and Tsichlis, P.N. (2005). AKT signaling in normal and malignant cells. Oncogene 24, 7391-7393.

Timar, J., Kasler, M., Katai, J., Soos, M., Mathiasz, D., Romany, A., Patthy, L., Kovacs, G., Jozsa, A., Szilak, L., et al. (2006). [Developments in cancer management by innovative genomics. 2006 report of the National Cancer Consortium]. Magy Onkol 50, 349-359.

Toyama, K., Wulff, H., Chandy, K.G., Azam, P., Raman, G., Saito, T., Fujiwara, Y., Mattson, D.L., Das, S., Melvin, J.E., et al. (2008). The intermediate-conductance calciumactivated potassium channel KCa3.1 contributes to atherogenesis in mice and humans. J Clin Invest 118, 3025-3037.

Trudeau, M.C., Warmke, J.W., Ganetzky, B., and Robertson, G.A. (1995). HERG, a human inward rectifier in the voltage-gated potassium channel family. Science 269, 92-95. 
Tsai, S.Y., Hayashi, T., Mori, T., and Su, T.P. (2009). Sigma-1 receptor chaperones and diseases. Cent Nerv Syst Agents Med Chem 9, 184-189.

Varadi, A., Cirulli, V., and Rutter, G.A. (2004). Mitochondrial localization as a determinant of capacitative $\mathrm{Ca}^{2+}$ entry in HeLa cells. Cell Calcium 36, 499-508.

Villalonga, N., Ferreres, J.C., Argiles, J.M., Condom, E., and Felipe, A. (2007). Potassium channels are a new target field in anticancer drug design. Recent Patents Anticancer Drug Discov 2, 212-223.

Wang, Q., Wang, L., Feng, Y.H., Li, X., Zeng, R., and Gorodeski, G.I. (2004). P2X7 receptormediated apoptosis of human cervical epithelial cells. Am J Physiol Cell Physiol 287, C1349-1358.

Wang, Z.H., Shen, B., Yao, H.L., Jia, Y.C., Ren, J., Feng, Y.J., and Wang, Y.Z. (2007). Blockage of intermediate-conductance- $\mathrm{Ca}\left({ }^{2+}\right)$-activated $\mathrm{K}\left({ }^{+}\right)$channels inhibits progression of human endometrial cancer. Oncogene 26, 5107-5114.

Waning, J., Vriens, J., Owsianik, G., Stuwe, L., Mally, S., Fabian, A., Frippiat, C., Nilius, B., and Schwab, A. (2007). A novel function of capsaicin-sensitive TRPV1 channels: involvement in cell migration. Cell Calcium 42, 17-25.

Weber, C., Mello de Queiroz, F., Downie, B.R., Suckow, A., Stuhmer, W., and Pardo, L.A. (2006). Silencing the activity and proliferative properties of the human EagI Potassium Channel by RNA Interference. J Biol Chem 281, 13030-13037.

Weerasinghe, R.R., Swanson, S.J., Okada, S.F., Garrett, M.B., Kim, S.Y., Stacey, G., Boucher, R.C., Gilroy, S., and Jones, A.M. (2009). Touch induces ATP release in Arabidopsis roots that is modulated by the heterotrimeric G-protein complex. FEBS Lett 583, 2521-2526.

White, N., Butler, P.E., and Burnstock, G. (2005). Human melanomas express functional P2 X(7) receptors. Cell Tissue Res 321, 411-418.

White, N., Knight, G.E., Butler, P.E., and Burnstock, G. (2009). An in vivo model of melanoma: treatment with ATP. Purinergic Signal 5, 327-333.

Wiley, J.S., Dao-Ung, L.P., Gu, B.J., Sluyter, R., Shemon, A.N., Li, C., Taper, J., Gallo, J., and Manoharan, A. (2002). A loss-of-function polymorphic mutation in the cytolytic P2X7 receptor gene and chronic lymphocytic leukaemia: a molecular study. Lancet 359, 1114-1119.

Wondergem, R., Ecay, T.W., Mahieu, F., Owsianik, G., and Nilius, B. (2008). HGF/SF and menthol increase human glioblastoma cell calcium and migration. Biochem Biophys Res Commun 372, 210-215.

Wulff, H., Miller, M.J., Hansel, W., Grissmer, S., Cahalan, M.D., and Chandy, K.G. (2000). Design of a potent and selective inhibitor of the intermediate-conductance $\mathrm{Ca}^{2+}$ activated $\mathrm{K}^{+}$channel, IKCa1: a potential immunosuppressant. Proc Natl Acad Sci U $S$ A $97,8151-8156$.

Yamamura, H., Ugawa, S., Ueda, T., Morita, A., and Shimada, S. (2008a). TRPM8 activation suppresses cellular viability in human melanoma. Am J Physiol Cell Physiol 295, C296-301.

Yamamura, H., Ugawa, S., Ueda, T., and Shimada, S. (2008b). Expression analysis of the epithelial $\mathrm{Na}^{+}$channel delta subunit in human melanoma G-361 cells. Biochem Biophys Res Commun 366, 489-492. 
Yohem, K.H., Clothier, J.L., Montague, S.L., Geary, R.J., Winters, A.L., 3rd, Hendrix, M.J., and Welch, D.R. (1991). Inhibition of tumour cell invasion by verapamil. Pigment Cell Res 4, 225-233.

Zhang, X.J., Zheng, G.G., Ma, X.T., Yang, Y.H., Li, G., Rao, Q., Nie, K., and Wu, K.F. (2004). Expression of $\mathrm{P} 2 \mathrm{X} 7$ in human hematopoietic cell lines and leukemia patients. Leuk Res 28, 1313-1322. 


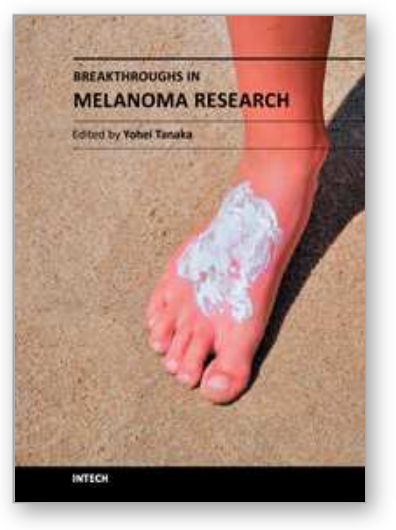

\author{
Breakthroughs in Melanoma Research \\ Edited by Dr Yohei Tanaka
}

ISBN 978-953-307-291-3

Hard cover, 628 pages

Publisher InTech

Published online 30, June, 2011

Published in print edition June, 2011

Melanoma is considered to be one of the most aggressive forms of skin neoplasms. Despite aggressive researches towards finding treatments, no effective therapy exists to inhibit the metastatic spread of malignant melanoma. The 5-year survival rate of metastatic melanoma is still significantly low, and there has been an earnest need to develop more effective therapies with greater anti-melanoma activity. Through the accomplishment of over 100 distinguished and respected researchers from 19 different countries, this book covers a wide range of aspects from various standpoints and issues related to melanoma. These include the biology of melanoma, pigmentations, pathways, receptors and diagnosis, and the latest treatments and therapies to make potential new therapies. Not only will this be beneficial for readers, but it will also contribute to scientists making further breakthroughs in melanoma research.

\title{
How to reference
}

In order to correctly reference this scholarly work, feel free to copy and paste the following:

Aurélie Chantôme, Marie Potier-Cartereau, Sébastien Roger, Christophe Vandier, Olivier Soriani and Virginie Joulin (2011). Ion Channels as Promising Therapeutic Targets for Melanoma, Breakthroughs in Melanoma Research, Dr Yohei Tanaka (Ed.), ISBN: 978-953-307-291-3, InTech, Available from:

http://www.intechopen.com/books/breakthroughs-in-melanoma-research/ion-channels-as-promisingtherapeutic-targets-for-melanoma

\section{INTECH}

open science | open minds

\author{
InTech Europe \\ University Campus STeP Ri \\ Slavka Krautzeka 83/A \\ 51000 Rijeka, Croatia \\ Phone: +385 (51) 770447 \\ Fax: +385 (51) 686166 \\ www.intechopen.com
}

\author{
InTech China \\ Unit 405, Office Block, Hotel Equatorial Shanghai \\ No.65, Yan An Road (West), Shanghai, 200040, China \\ 中国上海市延安西路65号上海国际贵都大饭店办公楼 405 单元 \\ Phone: +86-21-62489820 \\ Fax: +86-21-62489821
}


(C) 2011 The Author(s). Licensee IntechOpen. This is an open access article distributed under the terms of the Creative Commons Attribution 3.0 License, which permits unrestricted use, distribution, and reproduction in any medium, provided the original work is properly cited. 